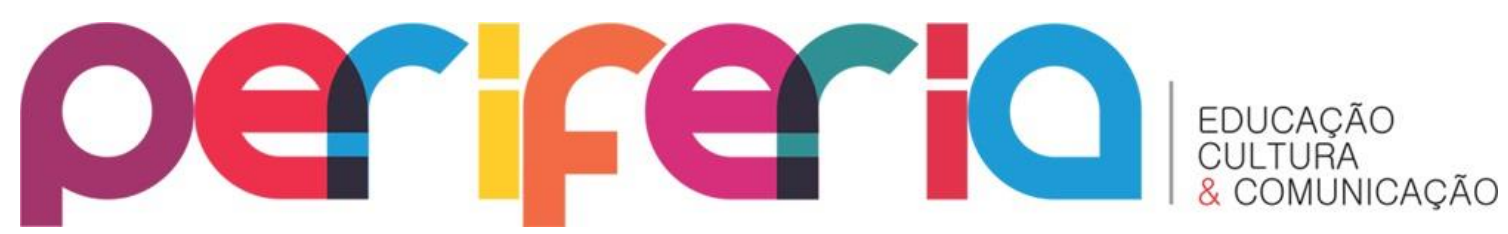

\title{
CANDOMBLÉS E CARNAVAIS: CORPOS DESFILANTES DE JOÃOZINHO DA GOMÉIA
}

\author{
Leonardo Augusto Bora ${ }^{1}$ \\ Gabriel Haddad Gomes Porto ${ }^{2}$ \\ Vinícius Ferreira $\mathrm{Natal}^{3}$
}

\section{RESUMO}

O trabalho investiga a presença de Joãozinho da Goméia enquanto "destaque de luxo" em desfiles de escolas de samba da cidade do Rio de Janeiro, no final da década de 1960 e no início da década de 1970. Objetiva-se, com isso, o estabelecimento de conexões entre o universo dos "barracões" das religiões de matrizes africanas e a complexidade dos "barracões" das agremiações carnavalescas. De início, as relações históricas entre escolas de samba, cosmogonias negro-africanas e sociabilidades de terreiros são problematizadas, com base em proposições teóricas de nomes como Paul Gilroy e Muniz Sodré. Num segundo momento, a partir da prospecção bibliográfica e do recorte de fragmentos jornalísticos, são apresentados apontamentos sobre a importância dos destaques de carnaval, com ênfase em personagens desempenhados por João da Goméia em desfiles de 1969 e 1970, em escolas como Império Serrano, Império da Tijuca e Imperatriz Leopoldinense. Depois, as lentes investigativas são direcionadas para a reinterpretação visual de algumas fantasias utilizadas pelo Babalorixá, conforme o proposto no decorrer do desfile de 2020 do GRES Acadêmicos do Grande Rio, cujo enredo Tata Londirá: o Canto do Caboclo no Quilombo de Caxias dedicou um "setor" (o equivalente a um capítulo de uma narrativa) aos corpos desfilantes do personagem homenageado. Conclui-se, por fim, que João da Goméia pode ser compreendido enquanto agente mediador que transitava por círculos culturais distintos, mesclando, na sua corporeidade carnavalesca, os saberes trocados nos terreiros de Candomblé e as vivências nas quadras (outrora chamadas "terreiros") e nos barracões do "maior show da Terra".

PALAVRAS-CHAVE: Joãozinho da Goméia; Candomblé; Carnaval; Escolas de Samba; Destaques

\footnotetext{
${ }^{1}$ Doutor em Teoria Literária (UFRJ), professor substituto da EBA-UFRJ e carnavalesco do GRES Acadêmicos do Grande Rio. E-mail: leonardobora@gmail.com

2 Mestre em Artes (UERJ) e carnavalesco do GRES Acadêmicos do Grande Rio. E-mail: gahgp@yahoo.com.br

${ }^{3}$ Doutor em Antropologia Cultural (UFRJ) e pesquisador do GRES Acadêmicos do Grande Rio.

E-mail: vfnatal@gmail.com
}

Periferia, v. 12, n. 3, p. 224-252, set./dez. 2020 


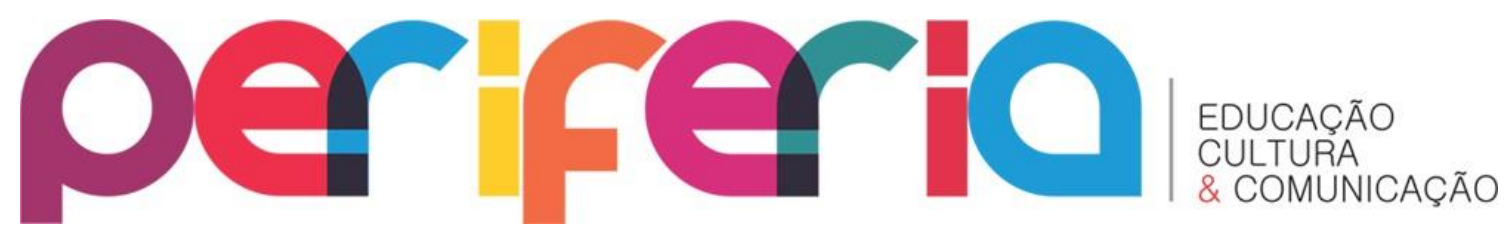

\section{CANDOMBLÉS AND CARNIVALS: CARNIVAL BODIES OF JOÃOZINHO DA GOMÉIA}

\section{ABSTRACT}

The work investigates the presence of Joãozinho da Goméia as a "luxury destaque" in samba school parades in the city of Rio de Janeiro, in the late 1960s and early 1970s., making connections between the universe of "barracões" of religions of African origin and the complexity of "barracões" of carnival groups. At first, the historical relations between samba schools, black African cosmogonies and the sociability of "terreiros" are questioned, based on theoretical propositions of names like Paul Gilroy and Muniz Sodré. In a second moment, from the bibliographic search and the clipping of journalistic fragments, notes are presented on the importance of the "destaques", with emphasis on characters played by João da Goméia in parades of 1969 and 1970, in schools like Império Serrano, Império da Tijuca and Imperatriz Leopoldinense. Then, the investigative lenses are directed to the visual reinterpretations of some fantasies used by the famous Babalorixá, as proposed during the 2020 parade of GRES Academicos do Grande Rio, whose plot Tata Londirá: o Canto do Caboclo no Quilombo de Caxias dedicated a "sector" (the equivalent of a chapter in a narrative) to the carnival bodies of the character honored. Finally, it is concluded that João da Goméia can be understood as a mediating agent that transited between different cultural circles, mixing, in his carnivalesque corporeity, the knowledge exchanged in the Candomblé "terreiros" and the experiences in the "quadras" (formerly called "terreiros") and in the "barracões" where the "biggest show on Earth" is built.

KEYWORDS: Joãozinho da Goméia; Candomblé; Carnival; Samba Schools; Destaques

\section{CANDOMBLÉS Y CARNAVALES: CUERPOS DESFILANDO DE JOÃOZINHO DA GOMÉIA}

\section{RESUMEN}

El trabajo investiga la presencia de Joãozinho da Goméia como un "destaque" de lujo en los desfiles de las escuelas de samba en la ciudad de Río de Janeiro, a fines de la década de 1960 y principios de la de 1970, haciendo conexiones entre el universo de "barracões" de religiones de origen africano y la complejidad de "barracões" de los grupos carnavaleros. En un primer momento se cuestionan las relaciones históricas entre las escuelas de samba, las cosmogonías negras africanas y la sociabilidad de los "terreiros", a partir de proposiciones teóricas de nombres como Paul Gilroy y Muniz Sodré. En un segundo momento, a partir de la búsqueda bibliográfica y el recorte de 


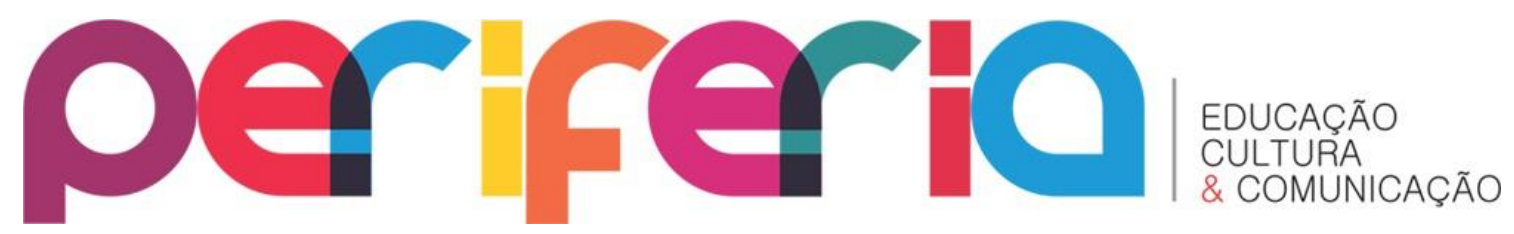

ISSN:1984-9540

DOI: $10.12957 /$ periferia.2020.55012

fragmentos periodísticos, se presentan apuntes sobre la importancia de los "destaques" del carnaval, con énfasis en los personajes interpretados por João da Goméia en desfiles de 1969 y 1970, en escuelas como Império Serrano, Império. da Tijuca e Imperatriz Leopoldinense. Luego, los lentes investigativos se dirigen a la reinterpretación visual de algunas fantasías empleadas por el Babalorixá, como se propuso durante el desfile de 2020 del GRES Academicos do Grande Rio, cuya trama Tata Londirá: o Canto do Caboclo no Quilombo de Caxias dedicada un "sector" (el equivalente a un capítulo en una narrativa) a los "cuerpos de carnaval" del personaje homenajeado. Finalmente, se concluye que João da Goméia puede entenderse como un agente mediador que transitó por diferentes círculos culturales, mezclando, en su corporeidad carnavalesca, los conocimientos intercambiados en los "terreiros" de Candomblé y las vivencias en las "quadras" (antes llamadas "terreiros") y en los "barracões" donde se construye el "mayor espectáculo de la Tierra".

PALABRAS CLAVE: Joãozinho da Goméia; Candomblé; Carnaval; Escuelas de Samba; Destaques

Introdução

“Malandro, Vedete, Herói, Faraó”. Talvez este trecho da letra do samba de enredo composto por Derê, Robson Moratelli, Rafael Ribeiro e Toni Vietnã para o desfile de 2020 do GRES Acadêmicos do Grande Rio seja uma das melhores formas de exemplificar a complexidade de um personagem chamado João Alves Torres Filho. Nascido na cidade de Inhambupe, na Bahia, João rumou a Salvador ainda jovem, atormentado por visões noturnas (o chamado espiritual do Caboclo Pedra Preta, que ele não compreendia ${ }^{4}$ ). $\mathrm{Na}$ capital baiana, supostamente trabalhou em mercados, espaços de trânsito onde conheceu lideranças candomblecistas. Devido às incuráveis dores de cabeça, procurou o auxílio do pai de santo Jubiabá. Não havia alternativa: ele precisava "fazer o santo”, terminologia que significa, nas religiões afro-brasileiras, cumprir o rito iniciático.

\footnotetext{
${ }^{4}$ Os detalhes dessas visões foram narrados para Gisèle Cossard e podem ser observados nas publicações que se debruçam sobre a vida do pai de santo, como a biografia Goméia João - $a$ arte de tecer o invisível, redigida por Carlos Nobre (2017).
}

Periferia, v. 12, n. 3, p. 224-252, set./dez. 2020 


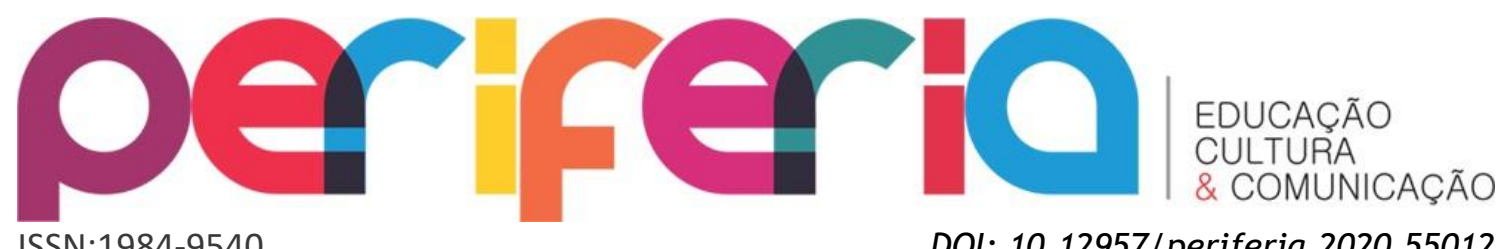

ISSN:1984-9540

DOI: 10.12957/periferia.2020.55012

Depois da feitura, em pouco tempo se tornou pai de santo: "João da Pedra Preta", "Tata Londirá". Fixou morada na "roça da Goméia", terreiro situado nos arredores da capital. Mas uma série de motivos o fizeram partir, na década de 1940, em direção ao Rio de Janeiro. 0 terreiro fundado em Duque de Caxias se transformou em um espaço-síntese para a compreensão da geografia sociocultural do município - e ganhou o apelido de "Nova Goméia", em alusão à "Goméia das antigas" (NOBRE, 2017, p. 35). Lá, o pai de santo recebia, com frequência, personalidades da grande mídia: Cauby Peixoto, Ângela Maria, Dercy Gonçalves, Abdias Nascimento, entre tantos e tantos nomes que marcaram as cenas artística, cultural, esportiva, política e intelectual do Brasil do século XX. As aparições de João eram frequentes nas páginas dos jornais, com destaque para a atuação nas públicas "guerras de demanda" (MAGGIE, 2001) e nas disputas pelas "cabeças" de filhos de santo, sem falar na coluna Ao cair dos búzios, do jornal Diário Trabalhista, entre 1949 e 1951 (RODRIGUES, 2020). A fama crescia, as polêmicas também.

Entretanto, a sua figura pública se construía não somente devido à atuação como líder religioso. Boa parte da fama jornalística se dava por conta de sua agência no cenário carnavalesco, onde vestiu opulentas fantasias nos grandes bailes do Rio de Janeiro (como os bailes do Automóvel Clube, do Theatro Municipal e do Hotel Glória). É surpreendente a percepção de que pouco se fala disso, nas pesquisas bibliográficas. E mais surpreendente é a ausência de um olhar aprofundado sobre a participação de Joãozinho nos desfiles das escolas de samba, universo em que se notabilizou como "destaque de luxo". Compreender as dimensões simbólicas do corpo carnavalesco do "Rei do Candomblé" e as suas atuações nas escolas de samba é algo de suma importância, pois, se entendermos o mundo dos destaques também como um espaço de trânsito e disputa, a presença do pai de santo enquanto ator nas tramas das agremiações, ao longo da década de 1960, nos mostra outras e complexas possibilidades de atuação - possibilidades que, como já foi dito, ainda não foram devidamente evidenciadas. 0 objetivo deste ensaio, portanto, é observar tal lacuna.

Periferia, v. 12, n. 3, p. 224-252, set./dez. 2020 


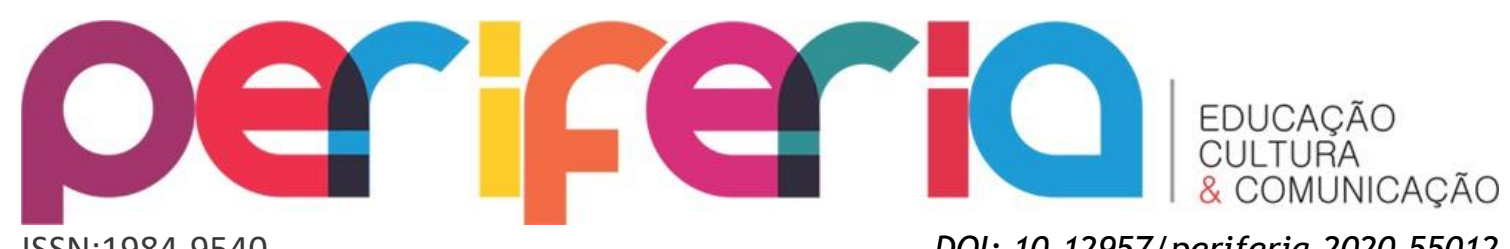

ISSN:1984-9540

DOI: $10.12957 /$ periferia.2020.55012

Num primeiro momento, as relações entre as escolas de samba e o universo religioso afro-brasileiro serão problematizadas; depois, enfocaremos a ideia de "destaque de luxo", refletindo brevemente sobre tal categoria e apresentando uma visão ampla, ancorada em fragmentos jornalísticos, acerca das participações de João nos desfiles; num terceiro momento, analisaremos o processo de reinterpretação temática empregado quando da concepção visual de 3 fantasias de alas do carnaval de 2020 do GRES Acadêmicos do Grande Rio - roupas que expressavam as participações do Babalorixá em desfiles do Império Serrano, do Império da Tijuca e da Imperatriz Leopoldinense. Com o intuito de mais fomentar perguntas do que pinçar respostas, defenderemos que João pode ser compreendido enquanto agente mediador que transitava por círculos culturais distintos, mesclando, na sua corporeidade carnavalesca, os saberes trocados nos terreiros de Candomblé e as vivências nas quadras e nos barracões das escolas de samba.

\section{Terreiros de Santo, Terreiros de Samba}

Entre os anos de 2015 e 2016, quando atuávamos no GRES Acadêmicos do Sossego (Gabriel Haddad e Leonardo Bora como carnavalescos e Vinícius Natal como diretor de carnaval), transitávamos pelos ateliês que confeccionavam as fantasias da referida escola, espalhados pelas cidades do Rio de Janeiro, Niterói e São Gonçalo. Um dos ateliês se localizava no bairro Viçoso Jardim, em Niterói, e era chefiado por Dona Lúcia Santos, costureira e mãe de santo. No espaço do seu terreiro, misturavam-se alguidares, imagens de gesso, rolos de tecidos e adereços de fantasias. A mãe e os seus filhos de santo produziam incessantemente. À medida que os elementos decorativos ficavam prontos, eles eram dispostos no espaço do terreiro - alguns eram guardados em recintos que não podíamos acessar. Percebíamos, nas experiências vivenciadas no terreiro de Mãe Lúcia, uma imbricação (com limiares tênues) entre carnaval e religião.

A memória dessa vivência foi uma constante durante o processo de confecção do carnaval de 2020 do GRES Acadêmicos do Grande Rio, escola de 


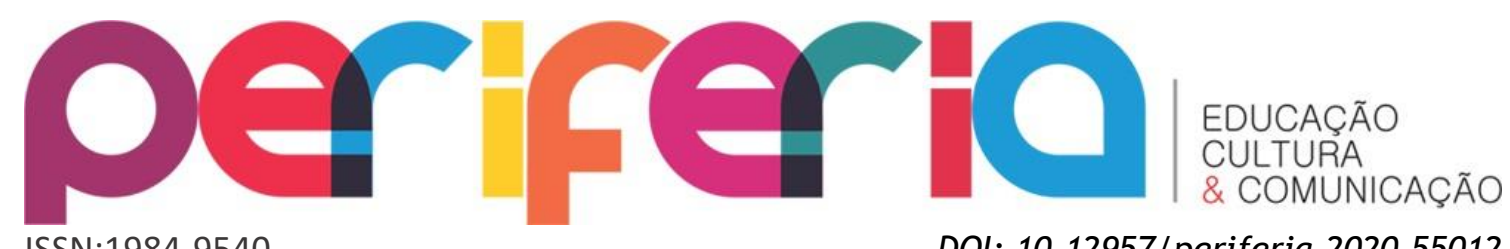

ISSN:1984-9540

DOI: $10.12957 /$ periferia.2020.55012 samba de Duque de Caxias, quando elaboramos uma narrativa em homenagem a Joãozinho da Goméia. Diariamente, lembrávamos do traço que unia, no espaço do barracão, os fazeres religiosos e os ditos "profanos" carnavalescos. Se já era sabido que existiam "barracões de alegoria" e "barracões de ala" (CAVALCANTI, 1994, p. 133), entrelaçávamos a essa dimensão a ideia de "barracão de santo", enxergando como a heterogeneidade cultural de uma cidade híbrida se desvelava em suas múltiplas dimensões a partir do “barracão", categoria que se desdobra em variados significados no universo afro-brasileiro.

De pronto, não nos cabe afirmar que barracão de escola de samba e barracão de santo significam a mesma coisa. Não nos cabe dizer, também, que um terreiro de escola de samba é uma tradução fidedigna de um terreiro religioso de axé, onde as macumbas e os sambas cariocas se conectam ao ponto de se tornarem uma coisa só. Entretanto, se atentarmos para o fio invisível da história que nos liga a um passado ancestral, vivido e sentido - tal qual Sankofa, avançar é retornar! -, compreendemos que a formação das culturas da diáspora negro-africana, a partir de uma intensa rede de sociabilidade negra tecida na cidade do Rio de Janeiro, contribuiu, fortemente, para uma conexão simbólica intrínseca a essas práticas no mundo contemporâneo.

Nesse sentido, é preciso observar as macumbas cariocas e o samba (e as escolas de samba, derivadas dele) como produtos da diáspora conectados a um mesmo "Atlântico Negro", local de encontro das culturas diaspóricas negroafricanas e, ao mesmo tempo, mola da reinvenção de práticas culturais nos mais diversos territórios do continente americano. O sociólogo Paul Gilroy (2002), ao apontar os contatos culturais que ocorriam não só entre escravizados, mas negros nas mais distintas posições, nos anima a pensar que tais relações propiciaram intensos intercâmbios e fluxos culturais entre diferentes etnias e modelos, principalmente nos campos artístico e musical. 0 Atlântico Negro, grande encruzilhada definida por Luiz Rufino como “disponibilidade para novos rumos, poética, campo de possibilidades, prática de invenção e afirmação da vida, perspectiva transgressiva à escassez, ao 


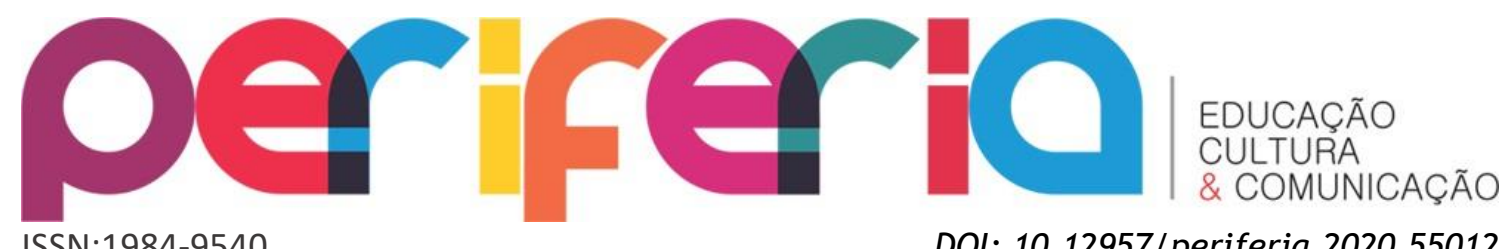

ISSN:1984-9540

DOI: $10.12957 /$ periferia.2020.55012 desencantamento e à monologização do mundo" (RUFINO, 2019, p.13), nos oferece a possibilidade de pensarmos os saberes da diáspora não somente na perspectiva da dor, mas também considerando a reelaboração semântica do próprio sentido da vida. Decolonialidade, pois sim.

Se este complexo de saberes afro-diaspóricos foi consolidado como uma forma de resistência e afirmação social do negro na cidade do Rio de Janeiro no período do pós-abolição, foi na sociabilidade da Praça Onze que samba e macumba ferviam em um mesmo caldo. Destaca-se, assim, a denominada “Pequena África”, expressão cunhada por Heitor dos Prazeres, em entrevista a Roberto Moura (2004), para demonstrar o complexo territorial que envolvia Saúde, Gamboa, Santo Cristo e arredores. Luiz Antônio Simas e Nei Lopes assim definiram o lugar: “concentrador de múltiplas expressões da cultura afrobrasileira, da música à religião, a Pequena África foi o berço onde nasceu o samba em sua forma urbana" (LOPES e SIMAS, 2015, p. 220). Inserida nesse amplo território, os mesmos autores definem a Praça Onze como um local onde as populações negras do Rio de Janeiro se exibiam no formato de escolas de samba e ranchos, "bem como se confraternizavam ou confrontavam, nas rodas de batucada e pernada" (LOPES e SIMAS, 2015, p. 225). Era lá que muitos negros herdeiros do período do pós-abolição travavam contato entre si e com a vida urbana das elites da cidade, transformando e ressignificando, constantemente, as suas práticas culturais.

Pode-se dizer que tanto na Pequena África quanto nas crescentes favelas do Rio de Janeiro as culturas da diáspora reelaboravam os seus laços e se redefiniam. Atentando para a nomenclatura "roda de samba", Roberto Moura, em No princípio era a roda (2004), atesta que a roda é uma prática sociocultural predecessora ao samba, valorizando a sociabilidade, o desafio, a convivência e a troca. Portadora de um espírito familiar, nascente das relações de proximidade entre escravizados e libertos oriundos e descendentes de África, a roda possuiria uma alma doméstica e comunitária, sendo prática fundamental nos cultos de matriz afro-brasileira e, em seguida, passando a ser praticada nos terreiros das escolas de samba, localizados nas favelas e nas regiões 


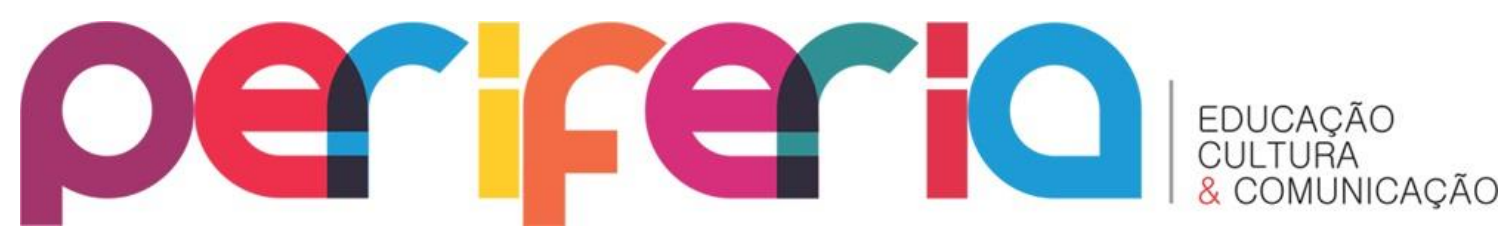

ISSN:1984-9540

DOI: $10.12957 /$ periferia. 2020.55012

historicamente à margem do coração financeiro da cidade. Tal conexão é reforçada quando miramos o dossiê das matrizes do samba do Rio de Janeiro e a sua definição de terreiros:

O terreiro, o nome dado às casas de Candomblé em todo o país, local de transmissão de conhecimentos, rituais de iniciação e integração, foi incorporado ao espaço do samba. A expressão terreiro remete à ideia de comunidade, de grupo familiar extensivo. Simbolicamente, pode ser entendido como o quintal dos sambistas, o terreno de ensaios das agremiações carnavalescas e outros lugares onde se cria, canta e dança o samba (DOSSIÊ, 2006, p.84).

É interessante atentar, também, para o depoimento de Dona Zica, líder feminina do Morro da Mangueira, ao relatar, conforme o exposto por Mônica Velloso, as funções desempenhadas pelas "Tias” Tomásia e Fé. Segundo Zica, tais matriarcas "desempenhavam o papel de verdadeiras chefes de uma 'grande família'. Suas casas reuniam múltiplas atividades, como Candomblé, samba, culinária e blocos carnavalescos" (VELLOSO, 1990, p. 215). Na sequência do exposto, Dona Zica complementa:

Na sexta-feira batia-se para o "povo da rua", no sábado para os orixás, no domingo era o dia do samba e da peixada. 0 pessoal normalmente ficava para dormir, porque no dia seguinte era o dia de "homenagear as almas". Quando a Mangueira ainda nem existia enquanto escola de samba, tanto a tia Fé como Tomásia já tinham os seus próprios blocos carnavalescos, onde saíam os seus "filhos de santo", com elas à frente, sempre vestidas de baiana (VELLOSO, 1990, p. 215).

Nesse mesmo contexto atuavam, na Pequena África, as tias baianas, mulheres importantes para a (re)constituição dos laços identitários negros. Tia Ciata, por exemplo, ao lado de outras, como Tia Bebiana e Tia Perciliana, atuava como uma importante mediadora entre diversos estratos sociais, pois, ao mesmo tempo em que possuía seus afazeres como zeladora de santo, articulava-se com políticos, intelectuais e músicos que frequentavam as suas 


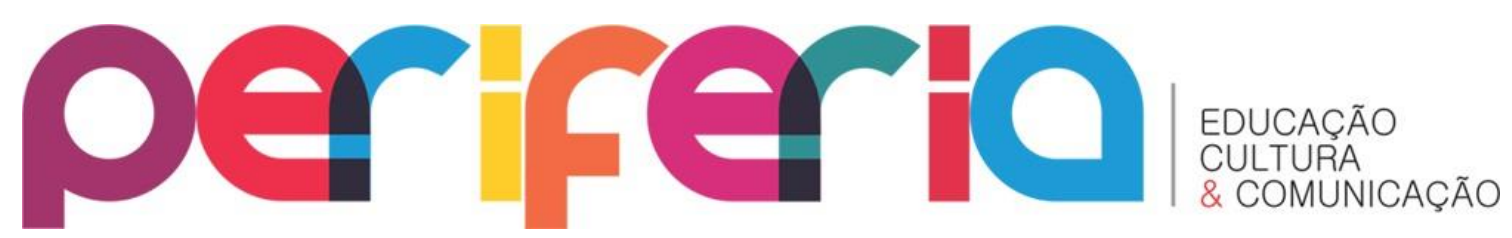

ISSN:1984-9540

DOI: $10.12957 /$ periferia. 2020.55012

festas. 0 seu terreiro, então, fazia-se um local de intensa sociabilidade, onde não só o samba e as macumbas eram tocados, mas também chorinho, maxixe e outros ritmos que ali vingavam ${ }^{5}$.

Compreendida a ideia de que macumbas e sambas possuíam estreita relação, é importante entender que Joãozinho da Goméia, nessa encruzilhada discursiva, pode ser lido dentro da chave de um corpo negro herdeiro da diáspora. Ao se portar como um dos principais líderes do Candomblé no Rio de Janeiro e ao se apresentar nas escolas de samba da cidade, foi um agente ativo e combativo, imbuído de uma estratégia de negociação que passava pela visão do seu corpo multifacetado - que atraía os holofotes para o seu terreiro, localizado em Duque de Caxias, na Baixada Fluminense. Se a sociedade brasileira ainda elege os seus principais heróis e intelectuais à luz de um pensamento eurocentrado, Joãozinho se mostra como um bom exemplo da possibilidade de construção de contra-narrativas ou narrativas contrahegemônicas sobre a cultura brasileira e as brasilidades. Luiz Antônio Simas chama a atenção para a nossa dificuldade em admitir que

os inventores do que há de mais forte na cidade do Rio de Janeiro não discutiram filosofia nas academias e universidades, não escreveram tratados, não pintaram os quadros do Renascimento, não foram convidados a frequentar bibliotecas, não compuseram sinfonias (...). Os nossos grandes inventores rufaram tambores, chamaram Zambiapungo e Olorum, riscaram o asfalto preenchendo de dança o intervalo entre as marcações do surdo, despacharam as encruzas, subiram o São Carlos e as escadarias da Penha, bradaram revividos em seus santos-cavalos nas matas e cachoeiras, celebraram os mortos na palma da mão (SIMAS, 2019, p.13-14).

Muniz Sodré, em Pensar Nagô, ao abordar a construção de modelos de pensamento a partir das religiões e culturas de matriz afro-brasileira, nos mostra que, diferentemente do pensamento cristão ocidental, as múltiplas

\footnotetext{
${ }^{5}$ Tamanha a sua fama, o terreiro de Ciata, lugar onde supostamente o "primeiro samba", Pelo telefone, foi composto, é mencionado em Macunaíma - o herói sem nenhum caráter, de Mário de Andrade.
}

Periferia, v. 12, n. 3, p. 224-252, set./dez. 2020 


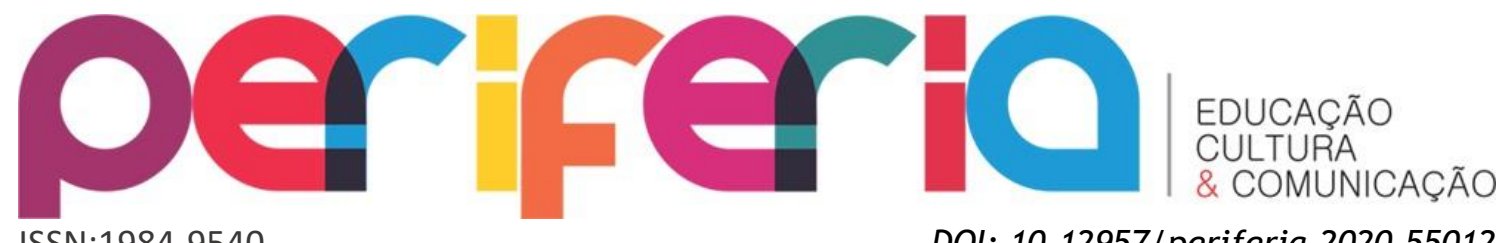

ISSN:1984-9540

DOI: $10.12957 /$ periferia.2020.55012 formas de atuação dos sujeitos herdeiros da diáspora negro-africana constituem, por si, uma forma de filosofia e pensamento ao privilegiarem o “pensar vivendo” e não o “viver pensando” (SODRÉ, 2017, p. 94). Sob tal visão, portanto, o corpo negro, macumbeiro, Igbtqia+ e carnavalesco de Joãozinho da Goméia se torna uma potente ferramenta para a construção de sentidos afrodiaspóricos na malha urbana do estado do Rio de Janeiro. Dançar, desfilar, exibir-se nas avenidas e nos salões seriam acontecimentos extraordinários de produção semântica e simbólica, eventos onde um corpo negro associado à Baixada Fluminense produzia formas de conhecimento e narrativas a partir de sua própria ação. Sodré define essa forma como "pensar nagô", uma "marcação cultural de limiares para posições singulares de crença e pensamento, portanto com a especificação de um sistema de pensamento, que caracterizamos como uma filosofia da diáspora" (SODRÉ, 2017, p. 220).

Expandindo a visão, pode-se pensar que a filosofia nagô é a valorização do coletivo, enquanto a filosofia ocidental preza pelo individualismo. 0 espaço dos terreiros de batuque e axé e, posteriormente, os terreiros de ensaios das escolas de samba, são, por excelência, lócus de reflexão filosófica de pensamentos a partir da liturgia das religiões afro-brasileiras e seus desdobramentos culturais coletivos. Ao circular nesses espaços, a figura de Joãozinho não só fazia valer a presença de seu corpo em transgressão, mas também tecia sentidos múltiplos e uma pedagogia própria, que abarcava religiosidade, gênero e raça. Quem quisesse aprender, que o observasse.

\section{Vestido para brilhar, vestido de realeza}

A edição de 4 de janeiro de 1967 do jornal Luta Democrática abordou os preparativos do Império Serrano para o carnaval de 1967. Em certo momento, lê-se:

Uma das grandes figuras da Império-67 é a do "Rei que não queria ser Rei" e que será interpretada por Joãozinho da Goméia (...). Joãozinho declarou que o seu traje, 


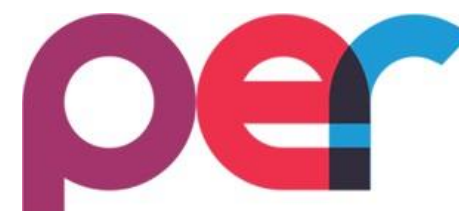

ISSN:1984-9540

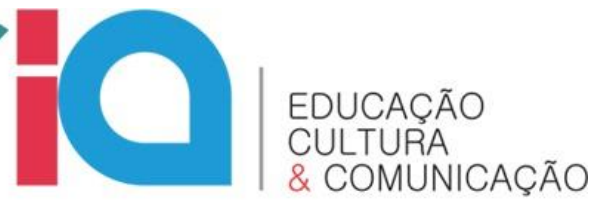

DOI: $10.12957 /$ periferia.2020.55012 indicado pela comissão de carnaval da escola, é muito custoso. Não apenas no que se refere aos gastos que efetuará, mas, também, pelo enorme trabalho que obrigará. Mas tudo estava bem, uma vez que só o prazer que iria ter em desfilar mais uma vez pela verde-ebranco, compensava todo o sacrifício (...) (LUTA DEMOCRÁTICA, p. 8).

Não é novidade o fato de que nos desfiles de ranchos e grandes sociedades, na primeira metade do século XX, determinados foliões já ocupavam "posições destacadas", interpretando personagens históricos e/ou mitológicos. O escritor Rubem Braga descreve, em crônica de fevereiro de 1949 intitulada Os Romanos, que as ruas do Leblon foram tomadas por algo que "não era escola de samba nem rancho direito, era apenas uma tentativa de rancho (...)" (BRAGA, 2011, p. 194). No alto de um carro alegórico, um folião vestido de Júlio César sintetizava a narrativa do cortejo: "Henredo o Império Romano" (BRAGA, 2011, p. 194). Há quem afirme que Paulo da Portela, no desfile de 1939 da escola de que herdou o "sobrenome", figurou enquanto destaque, uma vez que interpretou o professor do enredo Teste ao Samba. Os livros costumam dar a primazia ao Império Serrano: Olegária dos Anjos teria sido a primeira "destaque de luxo" do carnaval carioca, iniciando uma tradição que cintila até hoje. Em 1954, Dona Olegária interpretou Ceci no enredo O Guarani, com o qual a Serrinha conquistou o vice-campeonato 6 .

Se o pioneirismo está sujeito a debates, fato incontestável é que as escolas de samba do Rio de Janeiro viram, no decorrer das décadas de 1960 e 1970, o florescimento dos destaques de luxo, personalidades que trajavam roupas caras e exuberantes, como o traje de Xica da Silva vestido por Isabel Valença, no desfile de 1963 do Acadêmicos do Salgueiro. João Gustavo Melo entende que a presença hipnótica de Isabel Valença, uma mulher negra trajando um vestido inspirado em Maria Antonieta e uma altíssima peruca branca "ornada com pérolas" (COSTA, 2003, p. 94), no mesmo cortejo em que a bailarina Mercedes Baptista coreografou uma ala de minueto, na Avenida

\footnotetext{
${ }^{6}$ Sobre o referido desfile do Império Serrano, ver VALENÇA e VALENÇA, 2017, p. 111.
} 


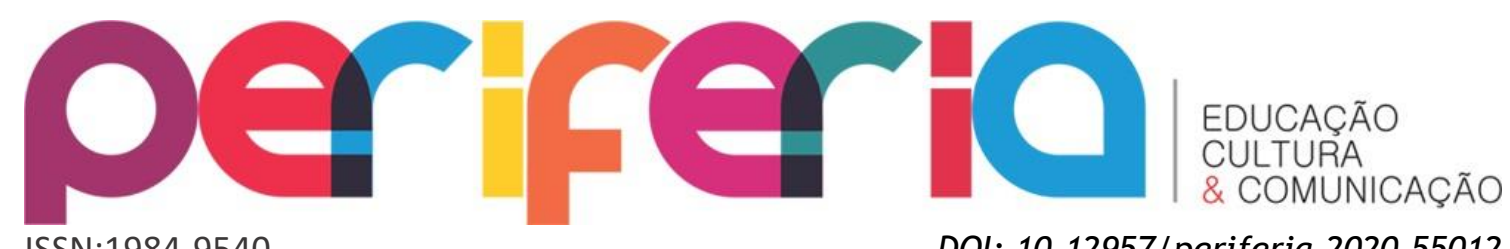

ISSN:1984-9540

DOI: $10.12957 /$ periferia.2020.55012

Presidente Vargas, expressa uma mudança de olhar para com a visualidade dos desfiles, ideia que nos leva à chegada de nomes como Marie Louise Nery, Fernando Pamplona e Arlindo Rodrigues ao Salgueiro, na virada das décadas de 1950 e 1960 (movimento que ficou conhecido como "Revolução Salgueirense"7). A presença cada vez maior de artistas plásticos, cenógrafos e figurinistas que transitavam por espaços como a Escola Nacional de Belas Artes (atual EBA UFRJ) e o Theatro Municipal alterou os paradigmas visuais e a própria narratividade dos desfiles. Nos termos de Melo, “a arte 'pura' das escolas de samba passava a ser cortejada não somente pelo mundo do teatro de revista, mas também por outras formas de espetáculo, como teatro, balé, ópera, cinema (...)" (MELO, 2018, p. 39).

Aos poucos, a estrutura dos carros alegóricos também sofreu alterações: eles se verticalizavam, suportando cada vez mais pessoas. 0 processo se intensificou na década de 1980, marcada pela construção do Sambódromo. Melo entende que a inauguração da Passarela do Samba, em 1984, e a transferência dos principais desfiles para um "palco" de dimensões monumentais contribuíram para o aumento do número total de destaques e, também, para o aumento do tamanho das fantasias, peças com complexas armações de ferro, repletas de plumas e elementos decorativos que expressam o chamado "luxo do brilho": broches, pedras, galões, franjas, pingentes, espelhos, pérolas, paetês, às vezes até mesmo luzes. Segundo a carnavalesca Rosa Magalhães, alguns trajes "eram tão grandes e pesados que usavam rodinhas, nas capas, para amenizar a dificuldade de caminhar. (...) Hoje vão em cima de luxuosos carros alegóricos" (MAGALHÃES, 1997, p. 46).

Melo, que compara os destaques sobre os carros alegóricos aos santos nos altares barrocos, afirma que, diante do crescimento das alegorias, "a presença de destaques no chão (...) ficou cada vez mais rara, embora ainda persistisse em algumas agremiações” (MELO, 2018, p. 72). Na década de 1960, porém, os desfiles ocorriam em algumas das principais avenidas do Centro do Rio de

${ }^{7}$ Sobre o tema, ver COSTA, 2003.

Periferia, v. 12, n. 3, p. 224-252, set./dez. 2020 


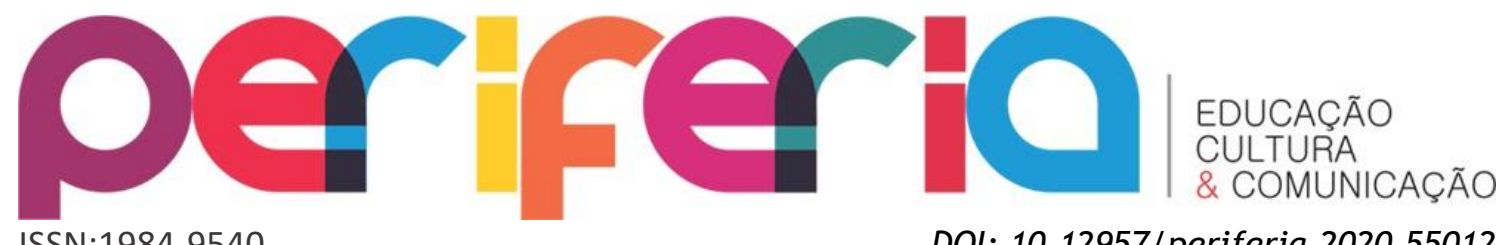

ISSN:1984-9540

DOI: $10.12957 /$ periferia.2020.55012 Janeiro: Rio Branco, Presidente Vargas (Candelária). Os destaques se apresentavam no chão, as capas tinham rodinhas.

É justamente na década de 1960, quando os destaques de luxo adquirem posição de centralidade nos cortejos e começam a se apresentar em outros espaços, como os concursos do Theatro Municipal ${ }^{8}$, que Joãozinho da Goméia se notabiliza como corpo desfilante que trajava, ano após ano, exuberantes fantasias em bailes e desfiles de escolas de samba: D. João VI, Pedro II, Ganga Zumba, Rei Nagô, Omolu, Ramsés II, Cleópatra, Vulcano, Netuno, foram muitos os personagens - todos os mencionados, não por coincidência, associados à ideia de realeza. Há que se destacar, de antemão, que Joãozinho era um exímio costureiro. Além dos relatos de matriz oral compartilhados por interlocutores que acompanharam a trajetória dele (caso de Maria Augusta Rodrigues, carnavalesca e ex-professora da EBA), a leitura da obra Vestidos de Realeza, de Andrea Mendes, dá a dimensão da importância que o universo da “indumentária” tinha para o pai de santo - e é inevitável não atentar para o paralelismo existente entre os títulos das obras de Melo (Vestidos para brilhar) e de Mendes (Vestidos de Realeza). A pesquisadora discorre sobre o uso de materiais associados a um imaginário de fausto e luxo:

Se as roupas usadas no cotidiano do terreiro eram feitas com tecidos simples de algodão, como o morim e a cambraia, as roupas de festa e, principalmente, as roupas dos inquices (denominadas "roupas de gala") eram confeccionadas com tecidos luxuosos: bordado Richelieu, bordado inglês, além de brocados, lamês, sedas e rendas (...) (MENDES, 2014, p. 96).

Haroldo Costa, ao analisar a confecção da icônica fantasia de Xica da Silva, enfatiza o requinte da peça e afirma que o orçamento "ficou em um milhão e trezentos mil cruzeiros" (COSTA, 2003, p. 74). Algumas reportagens falavam em “pedras preciosas autênticas” (MELO, 2018, p. 42), trabalho de ourivesaria. Mendes, quando investiga as camadas simbólicas das roupas cerimoniais da Goméia, também lança olhos para o uso de jóias:

\footnotetext{
${ }^{8}$ Isabel Valença, a Xica da Silva do desfile do Salgueiro de 1963, venceu, no ano seguinte, a categoria "luxo" do concurso do Theatro Municipal, com o traje Vila Rica. Tal vitória é pioneira e emblemática para o universo das escolas de samba.
}

Periferia, v. 12, n. 3, p. 224-252, set./dez. 2020 


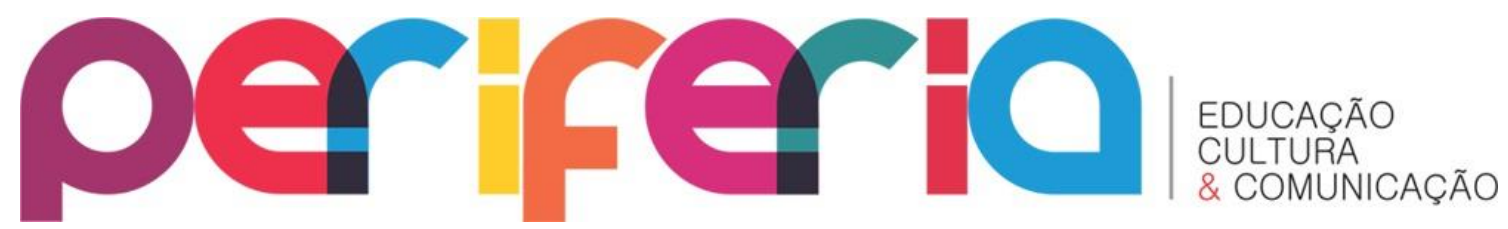

ISSN:1984-9540

DOI: $10.12957 /$ periferia.2020.55012

(...) Gisèle Cossard, ao descrever a indumentária de Oxum, se refere ao uso de sete ides, ou argolas douradas, nos pulsos, assim como os argolões dourados no pescoço. As argolas ou braceletes de metal eram de uso corrente no antigo Reino do Kongo, como foi descrito por Cavazzi; os sacerdotes xinguila, por exemplo, as portavam em quantidade nos braços, pernas e peito, além de correntes de ferro (...) (MENDES, 2014, p. 1387-139).

É flagrante a percepção de conexões entre o universo carnavalesco e as tramas simbólicas que enredam os rituais afro-ameríndios no que tange aos estudos de vestuário. Interessante, inclusive, é pensar em uma comparação entre a capa da edição de 23 de setembro de 1967 da revista $O$ Cruzeiro, que exibia, junto ao título Joãozinho da Goméia e os segredos do Candomblé, uma fotomontagem com "Joãozinho sentado, em plano médio (...)" com duas filhas de santo "mais ao fundo, de corpo inteiro, em planos de altura diferentes (...)" (MENDES, 2014, p. 123), e os ensaios fotográficos que ilustravam as capas e os interiores das edições d'O Cruzeiro dedicadas ao carnaval. Tais "edições especiais" colocavam em evidência as imagens de destaques de luxo de escolas de samba e bailes de gala. Mendes argumenta que a disposição das imagens na capa dedicada ao Candomblé "destacava" a indumentária dos fotografados, algo também perceptível nas capas que exibiam destaques trajando vestes exuberantes (imagens 1 e 2 ).
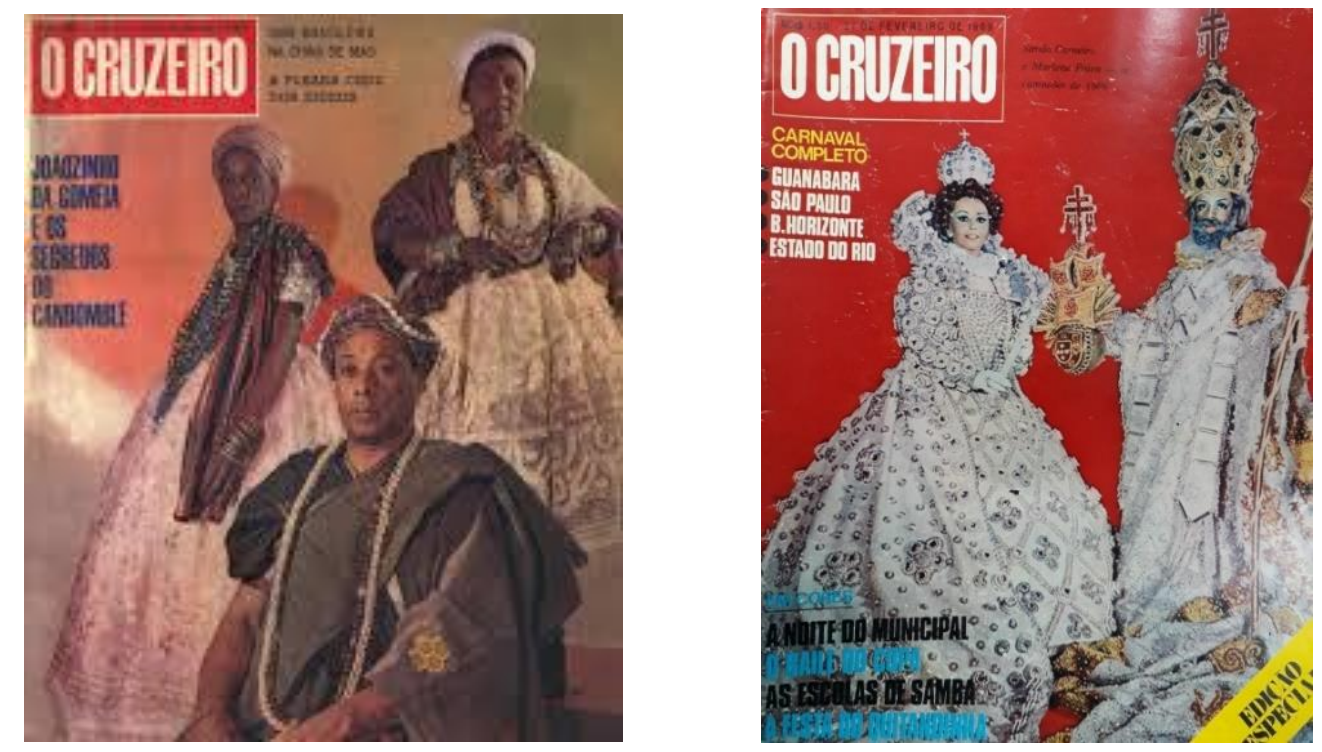

Periferia, v. 12, n. 3, p. 224-252, set./dez. 2020 


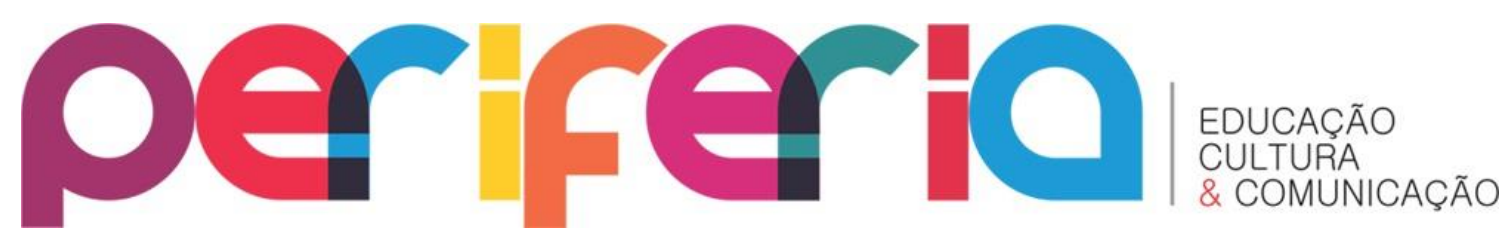

ISSN:1984-9540

DOI: $10.12957 /$ periferia.2020.55012

Imagens 1 e 2: capas das edições da revista $O$ Cruzeiro de 23/09/1967 (à esquerda) e

27 de fevereiro de 1969 (à direita).

As ideias apresentadas nos ajudam a entender o porquê de João da Goméia tanto ter se deixado seduzir pela visualidade dos destaques. Poucos são os estudos que mencionam as passagens de João pelas escolas de samba. A pesquisadora Elizabeth Castelano Gama informa que "depois do Candomblé, o carnaval era a maior paixão do pai de santo" (GAMA, 2014, p. 183). Ainda segundo ela, "nos depoimentos dos filhos de João, aparece sua ligação com as escolas de samba Império Serrano e Imperatriz Leopoldinense (...)" (GAMA, 2014, p. 184). Na sequência, a autora menciona a fantasia Associação Brasileira de Imprensa, vestida por João no carnaval de 1955, e a polêmica envolvendo a personagem Arlete, forma como ele se apresentou no baile de travestis do Teatro João Caetano, em 1956, trajando vestes femininas (meia arrastão, maiô, gargantilha, brincos, sapatos de salto, leque de plumas na cabeça). A aparição de Arlete escandalizou outras lideranças religiosas, transformando-se em um episódio que muito diz das tensões existentes entre candomblés e carnavais, corpos festivos (tra)vestidos para diferentes espaços ${ }^{9}$. No pré-carnaval de 1966, por exemplo, os jornais noticiaram com fervor que Joãozinho da Goméia encenaria um polêmico "ritual de Candomblé" durante o desfile do Império Serrano, cujo enredo era Glórias e Graças da Bahia. O pesquisador Carlos Nobre acrescenta alguns dados:

Nos dias de folia momesca, era comum seu João só retornar para a casa na quarta-feira de cinzas e olhe lá. Ele também, além de excelente dançarino, era visto com frequência desfilando no GRES Império Serrano e no GRES Imperatriz Leopoldinense, apesar de não admitir que falassem de carnaval dentro do terreiro. (...) JG chegou a fundar a Companhia de Dança Folclórica com a bailarina Mercedes Baptista (NOBRE, 2017, p. 180/181).

\footnotetext{
9 É válido destacar que, durante a preparação do enredo da Grande Rio, fomos questionados sobre o porquê de enfatizarmos a presença de Joãozinho no carnaval. Alguns entrevistados diziam que era algo "menos importante" para a compreensão do biografado - o que se choca com as palavras dele próprio. Na visão de tais pessoas, deveríamos limitar o enfoque aos ritos candomblecistas, a fim de fortalecer a imagem de João enquanto sacerdote, corpo sagrado, e não como folião, corpo profano. Ouvimos, entre outras coisas, que "apesar de sair fantasiado, João era muito homem" - ecos da secular homofobia.
}

Periferia, v. 12, n. 3, p. 224-252, set./dez. 2020 


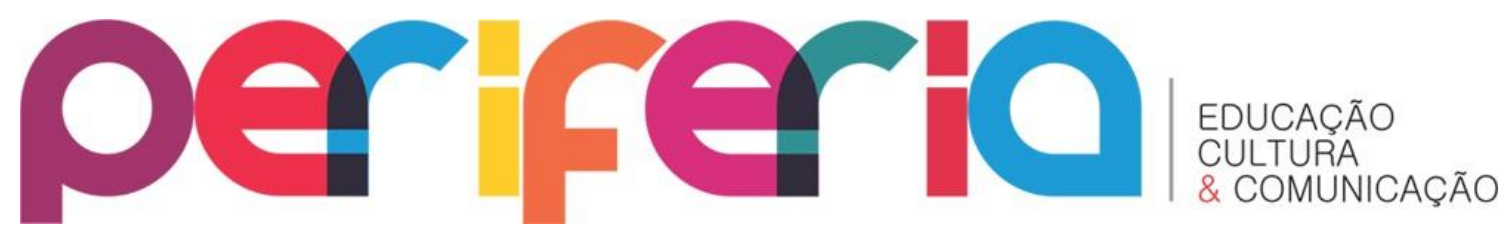

ISSN:1984-9540

DOI: $10.12957 /$ periferia.2020.55012

Ao mencionar, no mesmo trecho dedicado à presença de João nos desfiles das escolas de samba, a relação dele com Mercedes Baptista, Nobre toca em algo já desenhado neste trabalho: a progressiva penetração de artistas oriundos da Escola de Belas Artes e do Theatro Municipal nos corpos desfilantes das agremiações suburbanas. Como já foi mencionado, Mercedes foi a responsável pela coreografia de minueto, no desfile salgueirense de 1963. Fernando Pamplona e Arlindo Rodrigues também eram cenógrafos e figurinistas de teatro de revista, outro aspecto que não pode ser desconsiderado - afinal, é sabido que João da Goméia participou de alguns filmes (como Lina, a mulher de fogo, de $1958^{10}$ ) e espetáculos teatrais (são muitas as notícias sobre a participação dele e das filhas de santo em $A$ Casa da Viúva Costa, no Cassino Atlântico) graças à mediação do produtor Walter Pinto.

As informações sobre os trajes carnavalescos, porém, são precárias. Falamos de uma época em que a documentação dos desfiles dependia, em larga medida, da cobertura da imprensa escrita, que nem sempre especificava detalhes. Um exemplo é a menção a João em um desfile de 1970 (imagem 3), no interior da edição especial da revista Fatos e Fotos de 19 de fevereiro de 1970. O texto (cuja autoria não é informada) cita "o charme de Blecaute e o veneno de Joãozinho da Goméia” (FATOS E FOTOS, 1970, p. 22). Com base nisso, não é possível identificar a escola. A visão da fantasia e o cotejo com outros fragmentos, no entanto, nos permitem afirmar que se trata do traje confeccionado para a Imperatriz Leopoldinense, intitulado Rei Nagô. A edição do Jornal do Brasil de 4 de janeiro de 1970 ajuda a resolver o enigma: “Jackson do Pandeiro e Joãozinho da Goméia serão alguns dos sambistas que sairão como destaques. (...) Joãozinho, que veio do Império Serrano, será o Rei Nagô, e sua

10 O sítio da Cinemateca Brasileira informa a participação de "Walter Pinto e suas Beldades" nos números musicais do filme, bem como "Joãozinho da Colméia (sic) e seu Conjunto". Disponível em: http://bases.cinemateca.gov.br/cgi$\mathrm{bin} / \mathrm{wxis}$.exe/iah/?lsisScript=iah/iah.xis\&base=FILMOGRAFIA\&lang=p\&nextAction=Ink\&exprSea rch $=$ ID $=014096 \&$ format=detailed.pft. Acesso em 20/09/2020.

Periferia, v. 12, n. 3, p. 224-252, set./dez. 2020 


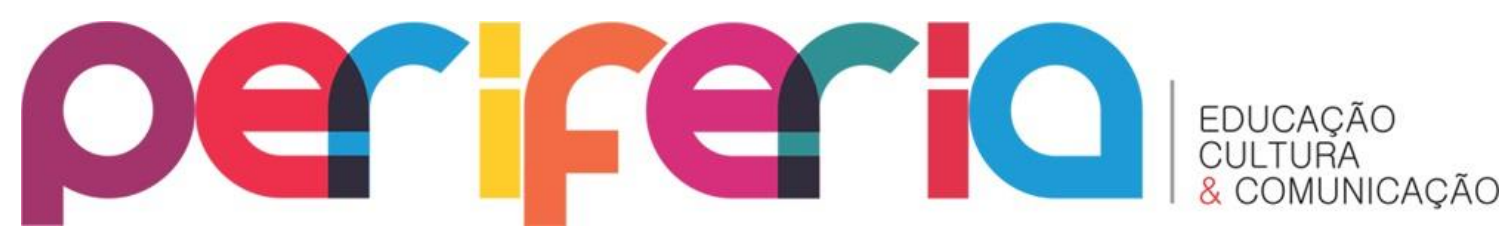

ISSN:1984-9540

DOI: $10.12957 /$ periferia. 2020.55012 ala levará todos os instrumentos de percussão do seu terreiro de macumba" (JORNAL DO BRASIL, 1970, p. 19).

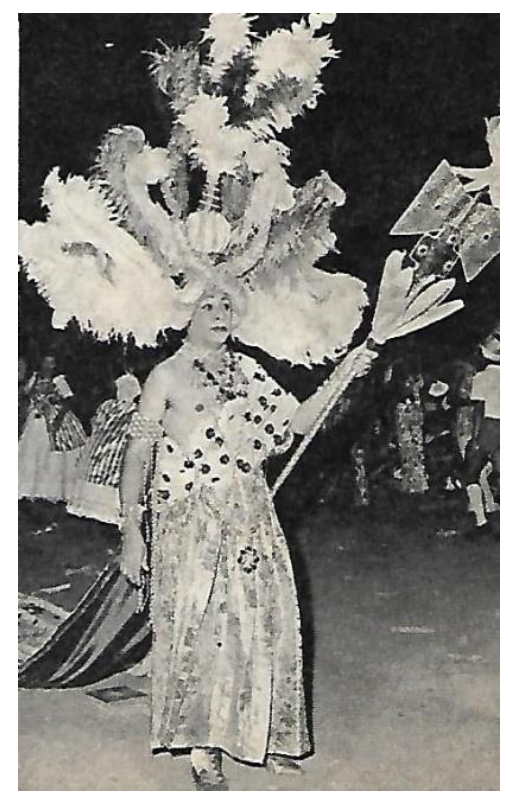

Imagem 3: João da Goméia desfilando em 1970. Foto da revista Fatos e Fotos de 19/02/1970, autoria não revelada.

Apresentado este panorama histórico, podemos mergulhar nas escolhas que fizemos a fim de expressar tal imaginário no desfile de 2020 do GRES Acadêmicos do Grande Rio. Selecionamos 3 fantasias de destaque de luxo utilizadas por João, com o objetivo de homenagear as escolas com as quais o pai de santo é automaticamente identificado: Império Serrano, Império da Tijuca e Imperatriz Leopoldinense. Os critérios utilizados para a seleção e as estratégias empregadas quando da tradução e da reinterpretação para fantasias de alas serão observados na sequência.

\section{Três faces de um Rei no Quilombo de Caxias}

O enredo Tata Londirá - o Canto do Caboclo no Quilombo de Caxias se propôs a mostrar diferentes facetas do personagem homenageado. Dividimos a narrativa em 6 "setores" - algo análogo aos capítulos de um livro, ou seja, 6 momentos narrativos que, unidos, formam um todo. No $1^{\circ}$ setor, a "abertura", 


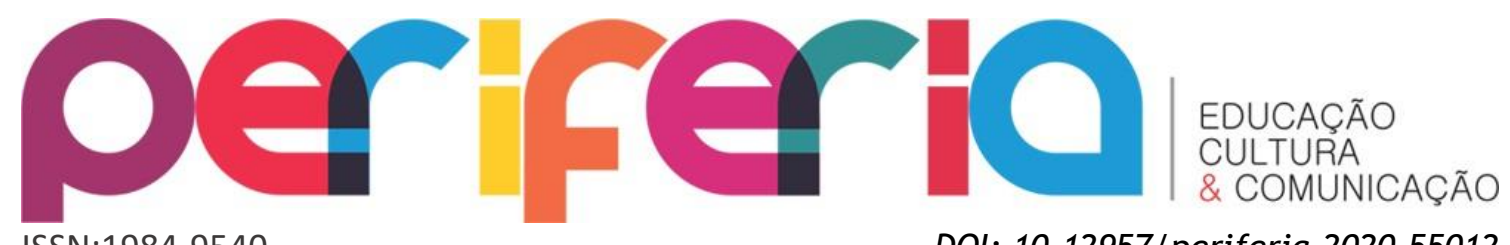

ISSN:1984-9540

DOI: $10.12957 /$ periferia.2020.55012 falamos das "raízes ancestrais" de João, menino de Inhambupe que se via atormentado por visões noturnas - o chamado do Caboclo Pedra Preta; no $2^{\circ}$ setor, abordávamos a iniciação de João nos ritos candomblecistas Angola, mencionando as festas populares de Salvador e a fundação da Goméia baiana; o $3^{\circ}$ setor contava a migração de João para a Baixada Fluminense: a fixação em Duque de Caxias e o culto aos caboclos em um terreiro que se transformava em aldeia; o $4^{\circ}$ setor enfatizava a paixão do homenageado pelo carnaval; no $5^{\circ}$ setor, o mundo das artes e dos espetáculos ganhava a cena, mostrando que João era uma figura midiática que atraía famosos do Brasil e do mundo, estimulando o imaginário coletivo; o $6^{\circ}$ e último setor celebrava a Goméia enquanto espaço mítico que reunia manifestações culturais e albergava as ideias de liberdade, diversidade e respeito - um canto em defesa do Povo de Axé, contra a intolerância religiosa e todo o tipo de preconceito.

O setor que tratava das relações de João da Goméia com o carnaval, portanto, era $04^{\circ}$, trecho este que foi divido em 3 momentos (espécies de “subcapítulos"): o $1^{\circ}$ falava dos bailes do Teatro João Caetano e da presença de Arlete, ou seja, do corpo transgressor do pai de santo que se travestia de vedete - justamente por isso, a ala lgbtqia+ da escola desfilou nesse subsetor, com leques e boás de plumas; o $2^{\circ}$ abordava os "bailes de gala" e o apreço de João por personagens da mitologia greco-romana e da História Antiga, como Netuno, Vulcano e Faraó Ramsés II (a fantasia da bateria); por fim, na $3^{\text {a }}$ parte eram enfocados os desfiles das escolas de samba e as relações de João com Império Serrano, Império da Tijuca e Imperatriz Leopoldinense. O carro Um saravá pra folia encerrava tal miscelânea, misturando elementos decorativos dos interiores do Theatro Municipal com as decorações de rua assinadas por Arlindo Rodrigues e Fernando Pamplona.

Definimos que cada uma das agremiações mencionadas merecia ser traduzida em uma fantasia de ala, ou seja, dedicaríamos 3 alas do desfile às experiências de João como destaque de escolas de samba, um tratamento equânime. Batido o martelo com relação a isso, era preciso selecionar 3 fantasias de destaque utilizadas pelo pai de santo, cada uma em uma das 


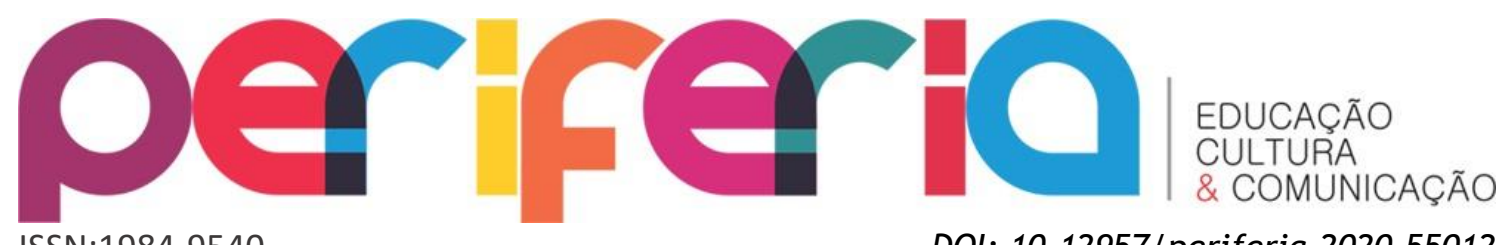

ISSN:1984-9540

DOI: $10.12957 /$ periferia.2020.55012

escolas, para que, a partir dessa escolha inicial, pudéssemos reprocessar as ideias em fantasias de alas, que, via de regra, são muito mais simples do que fantasias de destaques (é preciso lembrar que cada ala, no caso do desfile de 2020 da Grande Rio, reuniu em média 80 componentes; daí a ideia de que uma fantasia de ala precisa “funcionar no conjunto”). É de se supor que estávamos diante de um desafio, visto que há poucos registros documentais (fotográficos e/ou escritos) dessas fantasias. Tínhamos apenas uma certeza: no conjunto formado pelas 3 alas predominariam o branco, o verde e o ouro, cores compartilhadas pelas referidas agremiações. Um outro e expressivo ponto de contato é o fato de que tais escolas possuem a coroa como símbolo. Nas conversas com Maria Augusta Rodrigues e Seci Caxi (outra interlocutora permanente), uma ideia era constante: João desfilava nessas escolas por conta das cores e do símbolo. Sobre as cores, supostamente se tratava de uma exigência do Caboclo Pedra Preta; sobre o símbolo, há pouco a ser dito: o Rei do Candomblé se afeiçoava a escolas imperiais, cortes populares que ainda hoje representam o samba de Madureira e do Morro da Serrinha, no caso do Império Serrano, da Tijuca e do Morro da Formiga, no caso do Império da Tijuca, e de Ramos e do Morro do Alemão, no caso da Imperatriz Leopoldinense. ${ }^{11}$

A consulta das fontes jornalísticas permitiu que vislumbrássemos uma espécie de "linha do tempo" da trajetória carnavalesca de Joãozinho enquanto destaque de luxo. Ao que tudo indica, a primeira dessas agremiações em que o pai de santo desfilou sistematicamente como destaque foi o Império da Tijuca, vide uma notícia de 9 de dezembro de 1964, veiculada no Jornal do Brasil: “A escola deverá lançar o macumbeiro Joãozinho da Goméia na figura de destaque D. Pedro II, como atração" (IVAN e PORTELLA, 1964, p. 24). O mesmo jornal, em 4 de março de 1965, noticiou que ele permaneceu no Império da Tijuca e vestiu uma das fantasias mais caras do "carnaval do $4^{\circ}$ centenário" - D. João VI, fantasia inscrita no concurso do Municipal.

11 Curiosamente, as 3 agremiações não desfilaram no Grupo Especial, no carnaval de 2020 logo, não competiram com a Grande Rio, escola que não existia no período de que estamos falando. Produto de fusões, a tricolor de Caxias, tal qual a conhecemos hoje, foi fundada no dia 22 de setembro de 1988.

Periferia, v. 12, n. 3, p. 224-252, set./dez. 2020 


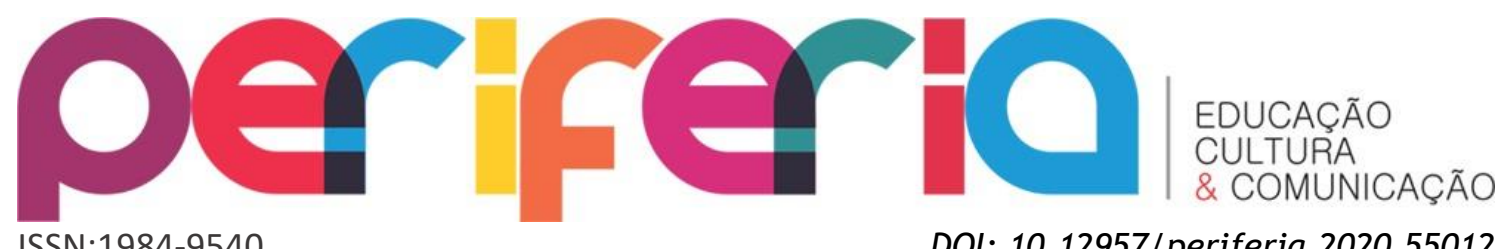

ISSN:1984-9540

DOI: $10.12957 /$ periferia.2020.55012

A transferência para o Império Serrano ocorreu no ano seguinte, 1966. As publicações muito enfatizaram a chegada de Joãozinho em Madureira, o que revela o prestígio de que ele gozava junto à imprensa. Na edição da Luta Democrática de 7 de janeiro de 1996 podiam ser lidas as palavras do destaque recém-chegado: “Quem não viu um Candomblé, não conhece a velha Bahia (...). Para conhecer tudo isso, basta acompanhar, agora, a Escola de Samba Império Serrano, onde ingressei com muita alegria e imensa satisfação” (LEMOS, 1966, p. 4). Não parece exagerado dizer que João da Goméia, devido à riqueza das roupas e às relações com celebridades, se tornou um destaque disputado - tanto assim que, no final de 1966, a imprensa noticiou uma "bomba": ele estaria entrando para o grupo de destaques do Salgueiro, possivelmente para desfilar com Isabel Valença ou Mercedes Baptista. A ida para a escola que consagrou Pamplona e Arlindo, porém, não ocorreu. O pai de santo continuou pelas bandas da Serrinha, interpretando, em 1969, o lendário Ganga Zumba.

Mas em 1970, João trocou a coroa do Império pela coroa da Imperatriz, escola em que supostamente já desfilava, de acordo com as narrativas orais. Ele batizou a bateria da Leopoldina, conforme atestam os jornais, e, em 24 de janeiro daquele ano, recebeu uma homenagem na quadra, junto de nomes como Raul Bopp, Di Cavalcanti e Luís Peixoto (BONIFÁCIO, 1970, p. 6). Sob o manto da "Rainha de Ramos", encarnou o Rei Nagô.

É preciso destacar que tal “linha do tempo" apresenta os seus momentos enovelados, curvas nebulosas onde as narrativas de matriz oral depositam os seus temperos. É fato que, para além dos desfiles noticiados, João pode (e deve) ter participado de outros cortejos. A relação com o Império da Tijuca, por exemplo, não sofreu uma "ruptura” quando da “migração" para o Império Serrano. É o que se deduz a partir da leitura de uma reportagem do Jornal do Brasil de 1 de fevereiro de 1967: “Dizem também que Joãozinho da Goméia vai sair na Império da Tijuca, justamente a escola que o lançou no samba” (JORNAL DO BRASIL, 1967, p. 26). Maria Augusta Rodrigues confirmou essa informação, atestando que, no mesmo carnaval em que foi Ganga Zumba, João confeccionou uma roupa de Omolu para o desfile da escola do Morro da Formiga.

Periferia, v. 12, n. 3, p. 224-252, set./dez. 2020 


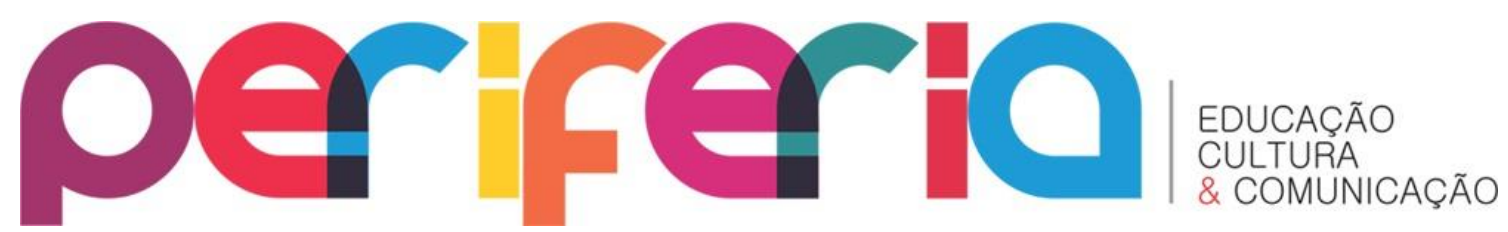

ISSN:1984-9540

DOI: $10.12957 /$ periferia.2020.55012

Realizadas a prospecção bibliográfica e as entrevistas, definimos que as fantasias a serem revisitadas seriam aquelas que mais diziam da personalidade negra de Joãozinho. Optamos por um recorte temático que valorizasse as realezas afro-brasileiras, estabelecendo a seguinte sequência de alas: Ganga Zumba - Império Serrano, "Heróis da Liberdade", 1969; Omolu - Império da Tijuca, "O Negro na Civilização Brasileira”, 1969; Realeza Nagô - Imperatriz Leopoldinense, "Oropa, França e Bahia", 1970. A concepção visual das fantasias, a arte-finalização dos croquis, a escolha dos materiais para a confecção dos protótipos e as alterações realizadas durante a fase da reprodução ficaram a cargo dos carnavalescos Gabriel Haddad e Leonardo Bora. As justificativas apresentadas no Livro Abre-Alas foram escritas a 6 mãos, em parceria com o pesquisador Vinícius Natal (responsável por coletar, nas etapas iniciais, os fragmentos jornalísticos).

A fantasia Ganga Zumba (imagem 4), procurou traduzir a força que envolve o lendário tio de Zumbi e líder do Quilombo de Palmares. No texto explicativo para o Livro Abre-Alas, disponível para consulta no sítio da LIESA ${ }^{12}$, escrevemos o seguinte:

A escola cantava o enredo Heróis da Liberdade, um grito contundente em tempos ditatoriais. 0 samba, de autoria de Silas de Oliveira, Mano Décio e Manoel Ferreira, entoava versos poderosos (...). O livro Serra, Serrinha, Serrano, de autoria de Rachel Valença e Suetônio Valença, reproduz a súmula do desfile apresentada à imprensa. A narrativa era desenvolvida em 10 atos, sendo o segundo intitulado Palmares. No texto, lê-se: "Mas o negro, cansado de tanta exploração, vai procurar onde possa ter um pouco de liberdade: Palmares, que depois é arrasada. As alas mostram escravos, reis e rainhas nativos: seis reis e seis rainhas. Destaques: 6 reis nativos, entre eles Ganga Zumba, encarnado por Joãozinho da Goméia; e Zumbi, por Geraldo.” (...) O figurino da ala, nas cores imperiais, mistura ráfia, palha e etafon, materiais amplamente utilizados na época. A lança e o escudo destacam o poder de Ganga Zumba, interpretado no cinema por Antônio Pitanga, no filme homônimo de Cacá Diegues de 1964. (...) A cabeça dos componentes

${ }^{12}$ Disponível em: http://liesa.globo.com/carnaval/livro-abre-alas.html. Acesso em $22 / 09 / 2020$

Periferia, v. 12, n. 3, p. 224-252, set./dez. 2020 


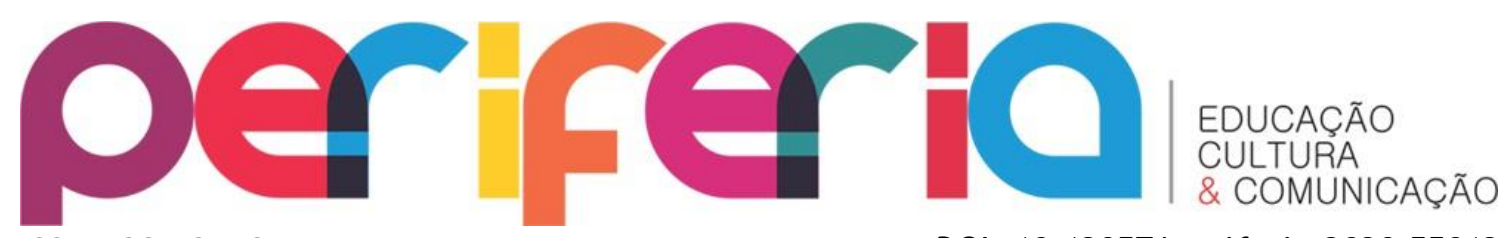

ISSN:1984-9540

DOI: $10.12957 /$ periferia.2020.55012

dialoga com elementos decorativos concebidos por Fernando Pamplona para a decoração do baile do Theatro Municipal de 1959, que tinha temática "afro" (BORA, HADDAD e NATAL, 2020, p. 343-344).

A concepção da fantasia Omolu (imagem 5) foi mais desafiadora, uma vez que se baseou tão somente nas palavras de Maria Augusta Rodrigues. No texto do Livro Abre-Alas, procuramos destacar tal característica do processo criativo:

(...) por mais estranho que possa parecer, não era comum a presença de orixás em desfiles de escolas de samba até a década de 1970. (...) É um dado que chama a atenção porque todos sabem das fortes ligações entre escolas de samba e casas de santo (...). Diante disso, não é difícil entender que Joãozinho da Goméia causou polêmica ao confeccionar a fantasia de Omolu. De acordo com Maria Augusta Rodrigues (que, juntamente com Alaíde Reis e Cláudia Miranda, todas indicadas por Fernando Pamplona, desenvolveu o projeto de figurinos do Império da Tijuca), a roupa foi feita com ráfia e palha e estava inserida no enredo $O$ negro na civilização brasileira. Por divergências internas, Augusta e Cláudia Miranda deixaram o projeto, que, na bibliografia carnavalesca, aparece como tendo sido executado pelo carnavalesco Arnaldo Pederneira. (...) Como tudo o que envolve a vida de João é marcado por particularidades, o desfile da escola do Morro da Formiga foi suspenso por problemas no som. No desfile da Grande Rio, vemos uma releitura muito afetuosa do Omolu de Joãozinho da Goméia. O figurino apresenta, assim como as demais fantasias do setor, elementos das saudosas decorações de rua (...). A máscara de crochê é um elemento fundamental, posto que Omolu não revela o próprio rosto. Atotô! (BORA, HADDAD e NATAL, 2020, p. 345-346).

Por fim, chegamos à fantasia Realeza Nagô (imagem 6). Decidimos presentear a galeria da Velha-Guarda da Grande Rio com a honrosa missão de homenagear a memória de uma coirmã. Isso fez com que não ficássemos presos à visão da fantasia original, ao contrário: procuramos criar um figurino feminino e um masculino que expressassem a elegância da Imperatriz Leopoldinense e a riqueza dos reinos africanos:

Periferia, v. 12, n. 3, p. 224-252, set./dez. 2020 


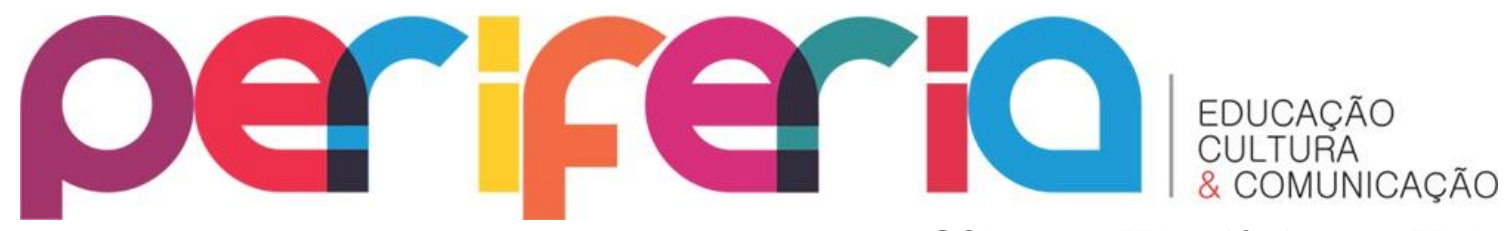

João, que já havia defendido a coroa de Leopoldina em outras apresentações (...), ganhou posição ainda mais destacada no desfile de 1970, quando a escola cantou o enredo Oropa, França e Bahia, uma leitura da brasilidade a partir da colagem de fragmentos literários de autores modernistas. A narrativa, assinada pelo Departamento Cultural da agremiação, era dividida em 9 quadros (...). $06^{\circ}$ quadro do desfile tratava do poema Funeral d'um Rei Nagô, de Murillo Araújo, posteriormente musicado e amplamente popularizado na voz de Inezita Barroso. 0 texto explicativo do enredo, a partir do poema de Araújo, exaltava: "É o Rei! venceu a dor! / E entre agogôs zoando, / archotes, pachorôs, babalaôs rezando, / O Rei vai vencedor!" $\mathrm{Na}$ apresentação da Imperatriz, João da Goméia interpretou o Rei Nagô, cercado por "tocadores de atabaques" e iaôs. No desfile da Grande Rio, a gloriosa galeria da Velha-Guarda foi escolhida para encarnar a Realeza Nagô outrora defendida por Joãozinho, numa carinhosa homenagem à coirmã do bairro de Ramos. Trajando vestes inspiradas em roupas cerimoniais africanas, nossos baluartes expressam a memória e a tradição, a sabedoria dos nossos antepassados, a imortalidade das nossas crenças e a permanência dos nossos valores (BORA, HADDAD e NATAL, 2020, p. 347348).

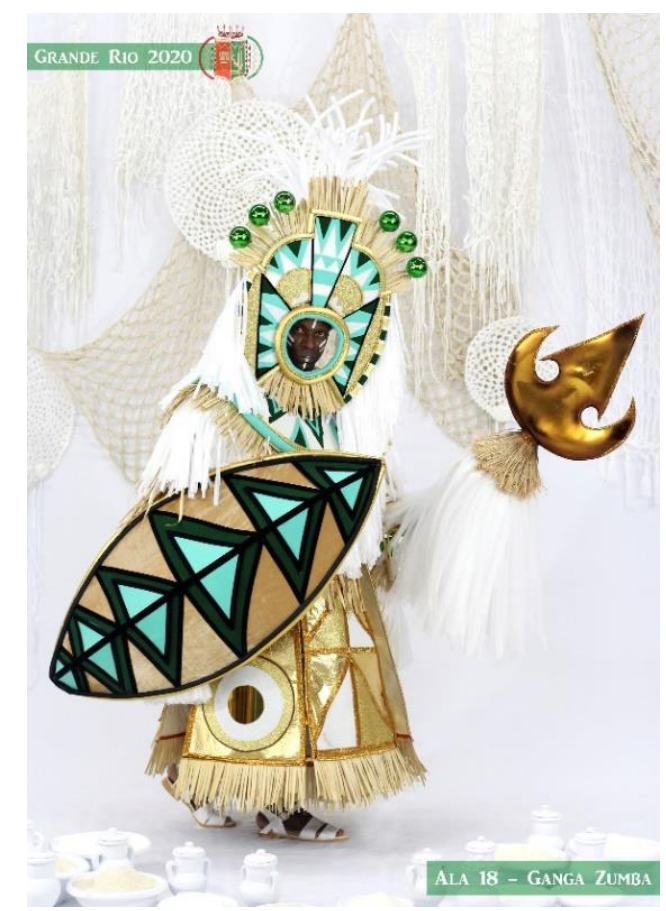

Imagem 4: Protótipo da fantasia Ganga Zumba. Foto de Ademir Jr. Acervo dos autores. 


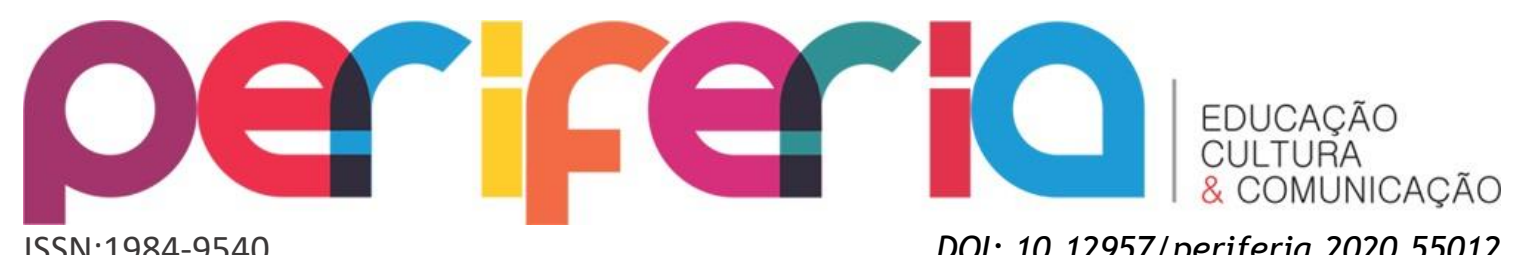

ISSN:1984-9540

DOI: $10.12957 /$ periferia.2020.55012

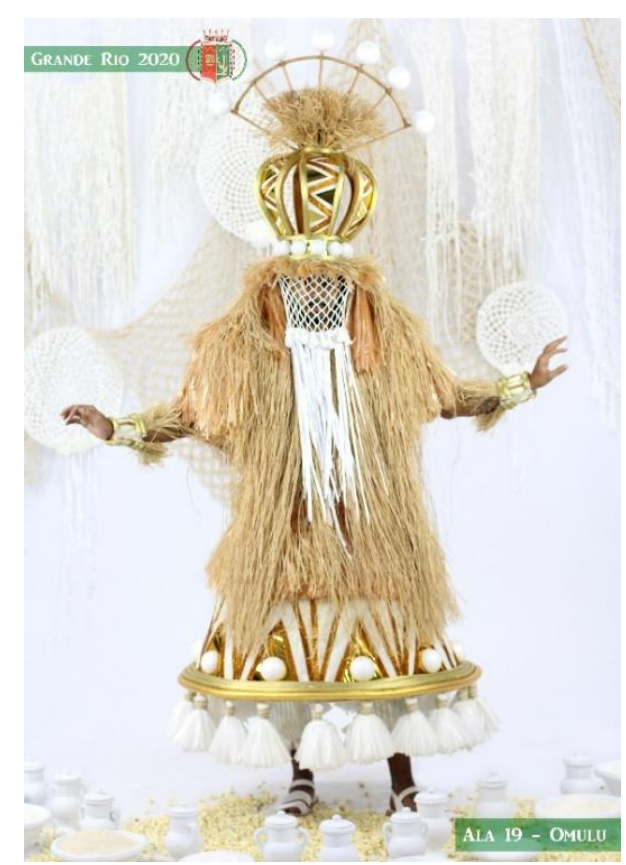

Imagem 5: Protótipo da fantasia Omolu. Foto de Ademir Jr. Acervo dos autores.

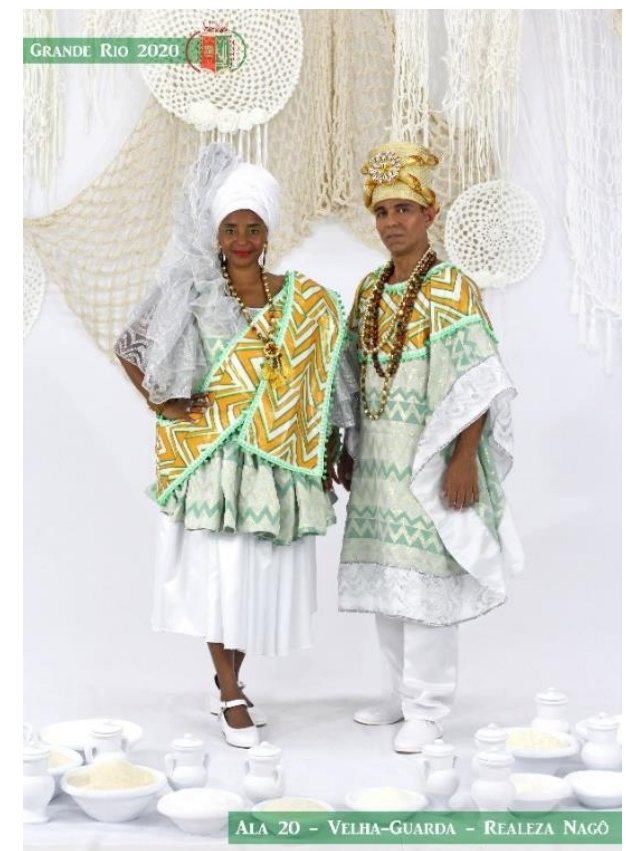

Imagem 6: Protótipos das fantasias Realeza Nagô. Foto de Ademir Jr. Acervo dos autores.

\section{Conclusão}

Periferia, v. 12, n. 3, p. 224-252, set./dez. 2020 


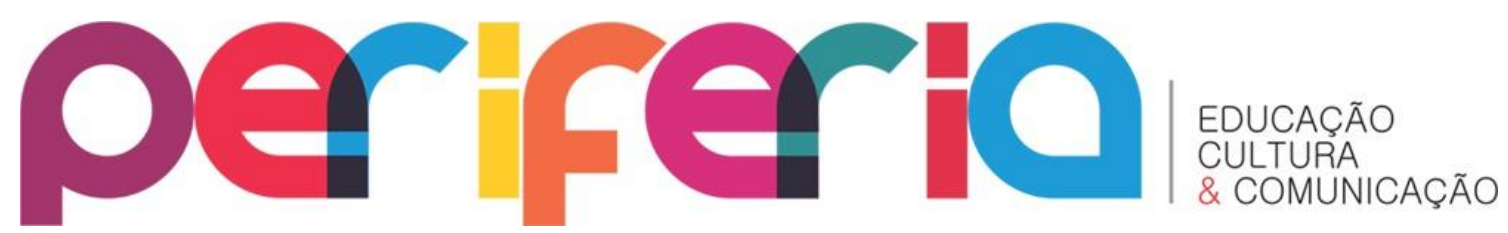

ISSN:1984-9540

DOI: $10.12957 /$ periferia.2020.55012

O painel apresentado no decorrer deste ensaio não deixa de ser um esboço marcado por cruzas de saberes, linguagens artísticas e espacialidades. O corpo desfilante de João da Goméia, inserido em uma encruzilhada cultural riscada por sandálias e sapatos bicolores sobre o asfalto das principais vias do Centro e dos subúrbios do Rio de Janeiro (e da Baixada Fluminense, por óbvio!), é um corpo múltiplo e inclassificável - daí ser mais adequado o uso do plural: corpos desfilantes. Corpos estes que, nos dias de Momo, circulavam pelos salões de bailes (para a alegria dos repórteres, que descreviam a presença do pai de santo com pitadas de excentricidade ${ }^{13}$ ), pelos barracões e pelas quadras das escolas de samba, pelos cortejos carnavalescos, sob as belas decorações. É interessante perceber que algumas notícias informam que ele comparecia a festas e premiações de escolas de samba acompanhado de "todo o seu terreiro" - caso de matéria do Jornal dos Sports de 5/12/1969, que noticiava a presença de João em uma festa para lansã, na quadra do GRES Arranco do Engenho de Dentro. Isso revela que ele participava de eventos religiosos e recreativos em agremiações que não apenas aquelas amplamente debatidas; e o fazia, segundo a notícia, acompanhado de filhos de santo. 0 fragmento nos ajuda a pensar a dimensão da popularidade adquirida por Joãozinho no contexto carnavalesco, ideia apresentada, repetidas vezes, por Maria Augusta Rodrigues.

João, em 1968, chegou a aparecer em "listas de grandes sambistas". 0 jornalista Arthur José Poerner publicou, no Correio da Manhã:

Da mesma forma que o futebol brasileiro, com Pelé, Jairzinho, Silva, Tostão, o samba também possui os seus grandes ídolos, como os acima citados e mais Carlinhos do Pandeiro, Jamelão, Delegado, Neide, Jupira e Neuma, da Mangueira; (...) Martinho, Pildes, Florinda e Jorge Vitorino, da Unidos de Vila Isabel; Natal, Oscar Bigode, Benício, Vilma e Odila, da Portela; Isabel Valença - mais conhecida por "Chica da Silva", fantasia com que desfilou

${ }^{13}$ É o caso observado na edição de 5 de março de 1960 da revista 0 Cruzeiro, onde se lê, na página 84: “(...) os deuses principais do Olimpo, por volta da meia-noite, dignar-se-iam descer para o convívio dos mortais: Vênus (vedete Carla Cabral), Vulcano (pai de santo Joãozinho da Goméia), etc. (...) Vulcano, blasé, ergueu então um brinde para comemorar a $20^{\mathrm{a}}$ briga havida no salão, desta vez entre um egípcio e um sujeito de blusão" (VASCONCELOS, p. 84).

Periferia, v. 12, n. 3, p. 224-252, set./dez. 2020 


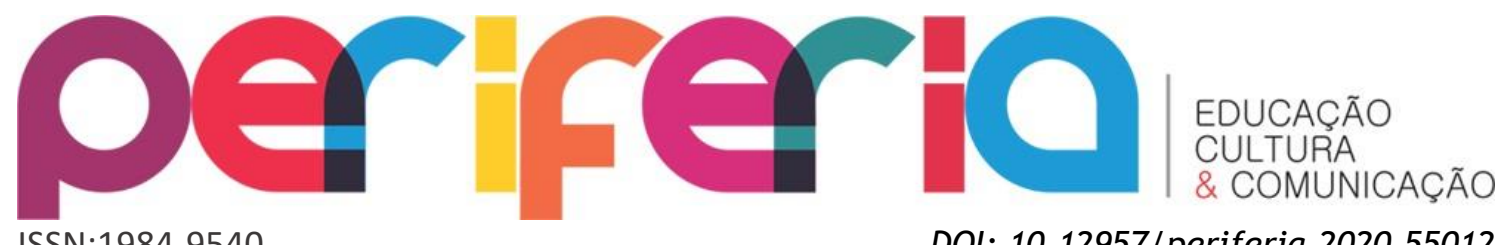

DOI: $10.12957 /$ periferia.2020.55012 em 1963 -, as Irmãs Marinho, a grande Paula e Narcisa, do Salgueiro; Joãozinho da Goméia, Silas de Oliveira, Sanziel (o Cidadão Recreativista) e o mestre-sala Noel Canelinha, da Império Serrano; e André, que comanda a bateria da Mocidade Independente de Padre Miguel (POERNER, 1968, p. 2).

O excerto não deixa dúvidas: João era visto como uma das personalidades mais representativas do Império Serrano, tanto que é citado ao lado de Silas de Oliveira. Tamanha importância nos leva à aparição do nome do pai de santo na "súmula" de Heróis da liberdade, algo mais do que significativo. Os corpos desfilantes se inscreviam na gramática cênica dos desfiles, nos documentos da época, nas narrativas em sentido amplo. Os corpos de João, em suma, circulavam, numa perspectiva tão cara aos estudos de mediação cultural. Dito isso, não parece descabido concluir que João da Goméia pode ser compreendido enquanto agente mediador que transitava por círculos culturais distintos, mesclando, nas suas corporeidades carnavalescas, os saberes trocados nos terreiros de Candomblé e as vivências nas quadras e nos demais espaços que ajudam a compor a geografia carnavalesca de uma cidade tão complexa como o Rio de Janeiro.

No entanto, como não poderia deixar de ser (estamos falando de João da Goméia!), há os pontos tortuosos, prenhes de contradição. Se, em 1968, Tata Londirá foi elencado entre os grandes sambistas da cidade, anos antes ele despertou polêmica, conforme se depreende do seguinte fragmento de uma entrevista com Antônio Santos, Diretor-Geral do Império Serrano:

Quanto aos argumentos de algumas pessoas de que o Império fez mal em colocar gente que não pertence ao samba autêntico, como Evandro Castro Lima e Joãozinho da Goméia, disse: “- Isto não é certo, porque adere ao samba quem bate bem o samba, e isso vale até para estrangeiros" (JORNAL DO BRASIL, 1966, p. 5).

A pergunta do entrevistador (cujo nome não é revelado) sugere que, para alguns críticos, a presença de João da Goméia se opunha à “autenticidade” do samba - e não deixa de ser fascinante perceber o quanto as discussões que 


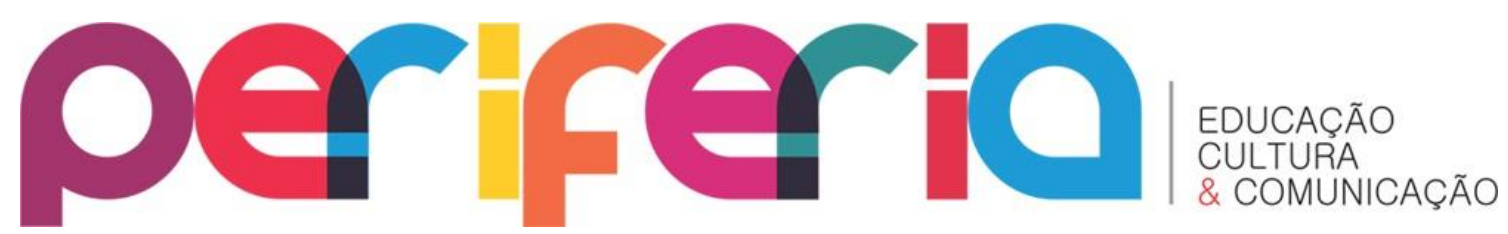

ISSN:1984-9540

DOI: $10.12957 /$ periferia. 2020.55012

giram em torno das ideias de "autenticidade", "originalidade" e "verdade" permanecem mais vivas do que nunca. Também desperta curiosidade o fato apregoado por inúmeros interlocutores de que João não gostava de falar de carnaval nem misturava o samba e a macumba. Tais espinhosos ouriços, porém, ficam para um próximo desfile - repleto de brilhos, bafafás e fuzuês.

\section{REFERÊNCIAS}

BONIFÁCIO, Aroldo. Momo 70. Correio da Manhã, Rio de Janeiro, ano LXIX, n. 23549, 22 de janeiro de 1970, p. 6.

BORA, Leonardo; HADDAD, Gabriel; NATAL, Vinícius. Tata Londirá: o Canto do Caboclo no Quilombo de Caxias. Livro Abre-Alas. Domingo - 2020. Disponível no sítio: http://liesa.globo.com/carnaval/livro-abre-alas.html. Acesso em 22/09/2020.

BRAGA, Rubem. 200 Crônicas Escolhidas. Rio de Janeiro: BestBolso, 2011.

CAVALCANTI, Maria Laura Viveiros de Castro. Carnaval carioca: dos bastidores ao desfile. Rio de Janeiro: Editora UFRJ, MinC/Funarte, 1994.

CAVALCANTI, Maria Laura Viveiros de Castro. $O$ rito e o tempo: ensaios sobre o carnaval. Rio de Janeiro: Civilização Brasileira, 1999.

COSTA, Haroldo. Salgueiro. 50 anos de glória. Rio de Janeiro/São Paulo: Record, 2003.

DOSSIÊ DAS MATRIZES DO SAMBA NO RIO DE JANEIRO (2006). Documento elaborado pelo IPHAN e disponível no sítio eletrônico www.iphan.gov.br. Acesso em 21/09/2020.

FATOS E FOTOS. Especial - Carnaval 70. Brasília, ano X, n. 472, 19 de fevereiro de 1970, p. 22.

GAMA, Elizabeth Castelano. Mulato, homossexual e macumbeiro: que rei é este? Trajetória de João da Goméia (1914-1971). Duque de Caxias, APPH-CLIO, 2014.

GILROY, Paul. O Atlântico Negro: modernidade e dupla consciência. São Paulo; Rio de Janeiro: 34/ UCAM, Centro de Estudos Afro-Asiáticos, 2002.

IVAN, Mauro; PORTELLA, Juvenal. O samba cá entre nós. Jornal do Brasil, Rio de Janeiro, ano LXXIV, n. 290, 9 de dezembro de 1964, p. 24. 


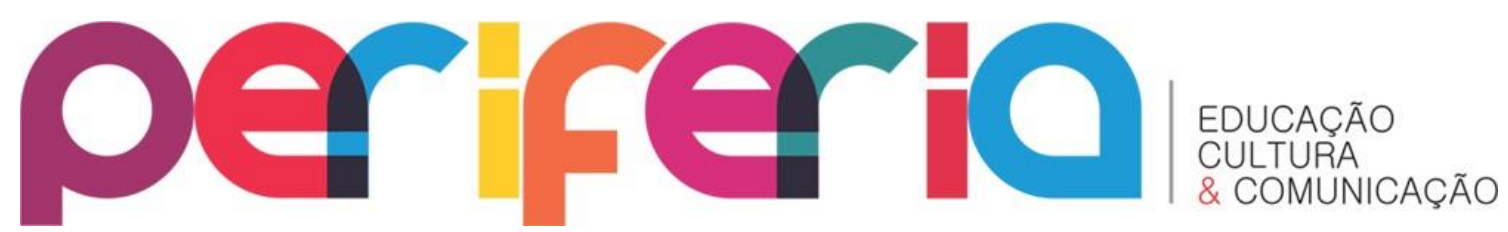

ISSN:1984-9540

DOI: $10.12957 /$ periferia.2020.55012

JORNAL DO BRASIL. Imperatriz, o Modernismo de 70. Rio de Janeiro, ano LXXIX, n. 231, 4 de janeiro de 1970, p. 19.

JORNAL DO BRASIL. Obra de Vicente Guimarães é enredo da Império da Tijuca. Rio de Janeiro, ano LXXVI, n. 27, 1 de fevereiro de 1967, p. 26.

JORNAL DO BRASIL. Portela ganha carnaval com 1 ponto à frente da Mangueira. Rio de Janeiro, ano LXXV, n. 46, 26 de fevereiro de 1966, p. 5.

LEMOS, Antônio. Império Serrano terá bonito enredo e Joãozinho da Goméia. Luta Democrática, Rio de Janeiro, ano XII, n. 3653, 7 de janeiro de 1966, p. 4.

LOPES, Nei; SIMAS, Luiz Antônio. Dicionário da História Social do Samba. Rio de Janeiro: Civilização Brasileira, 2015.

LUTA DEMOCRÁTICA. Império-67 mais forte que nunca. Rio de Janeiro, ano XIII, n. 3958, 4 de janeiro de 1967, p. 8.

MAGALHÃES, Rosa. Fazendo Carnaval. Rio de Janeiro: Lacerda Editores, 1997.

MAGGIE, Yvone. Guerra de Orixá: Um estudo de ritual e conflito. Rio de Janeiro: Zahar, 2001.

MELO, João Gustavo. Vestidos para Brilhar. Uma epopéia dos grandes destaques do carnaval carioca. Brasília: Rico, 2018.

MENDES, Andrea. Vestidos de Realeza. Fios e nós centro-africanos no Candomblé de Joãozinho da Goméia. Duque de Caxias: APPH-CLIO, 2014.

MOURA, Roberto. No princípio, era a roda: um estudo sobre samba, partidoalto e outros pagodes. Rio de Janeiro: Rocco, 2004.

NOBRE, Carlos. Goméia João. A arte de tecer o invisível. Rio de Janeiro: Centro Portal Cultural, 2017.

RODRIGUES, Monique. Ao cair dos búzios: Joãozinho da Goméia. Disponível em: https: / /dmjracial.com/2020/02/21/ao-cair-dos-buzios-joaozinho-dagomeia/. Acesso em 18/09/2020.

RUFINO, Luiz. Pedagogia das Encruzilhadas. Rio de Janeiro: Mórula Editorial, 2019.

SIMAS, Luiz Antônio. O corpo encantado das ruas. Rio de Janeiro: Civilização Brasileira, 2019.

SODRÉ, Muniz A. C. Pensar Nagô. Rio de Janeiro: Vozes, 2017.

VALENÇA, Rachel; VALENÇA, Suetônio. Serra, Serrinha, Serrano. O Império do Samba. Rio de Janeiro/São Paulo: Record, 2017.

Periferia, v. 12, n. 3, p. 224-252, set./dez. 2020 


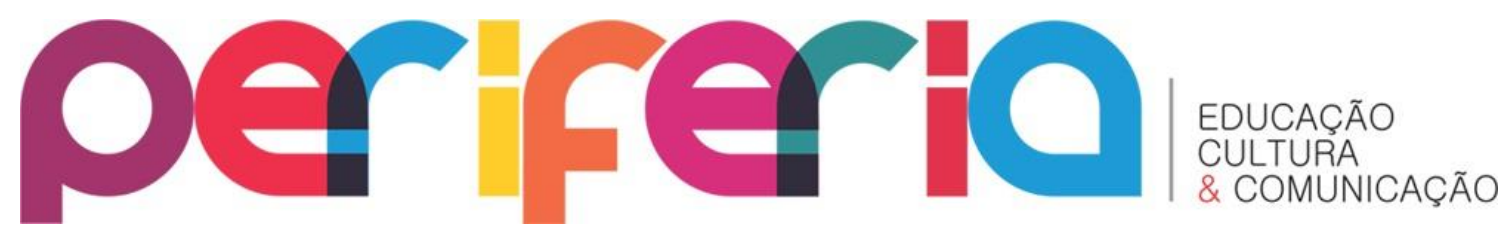

ISSN:1984-9540

DOI: $10.12957 /$ periferia.2020.55012

VASCONCELOS, Ary. Coliseu. Deuses desceram nos salões do Flamengo. $O$ Cruzeiro, Rio de Janeiro, edição 21, 5 de março de 1960, p. 84.

VELLOSO, Mônica Pimenta. As tias baianas tomam conta do pedaço: espaço e identidade cultural no Rio de Janeiro. Rio de Janeiro: Estudos Históricos, vol. 3, n. 6, 1990. Disponível em:

https://academiadosamba.com.br/monografias/velloso.pdf. Acesso em 20/09/2020.

http://bases.cinemateca.gov.br/cgi-

bin/wxis.exe/iah/?lsisScript=iah/iah.xis\&base=FILMOGRAFIA\&lang=p\&nextActi on=lnk\&exprSearch=ID=014096\&format=detailed.pft. Acesso em 20/09/2020. 